\title{
"The performance and risk of banks in the U.S., Europe and Japan post-financial crisis"
}

AUTHORS

ARTICLE INFO

DOI

RELEASED ON

JOURNAL

FOUNDER
Robert A. Weigand

Robert A. Weigand (2016). The performance and risk of banks in the U.S., Europe and Japan post-financial crisis. Investment Management and Financial Innovations, 13(4), 75-94. doi:10.21511/imfi.13(4).2016.07

http://dx.doi.org/10.21511/imfi.13(4).2016.07

Thursday, 15 December 2016

"Investment Management and Financial Innovations"

LLC "Consulting Publishing Company "Business Perspectives"

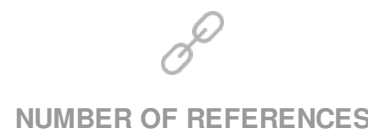

0
NUMBER OF FIGURES

0

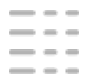

NUMBER OF TABLES

0

(C) The author(s) 2023. This publication is an open access article. 
Robert A. Weigand (USA)

\title{
The performance and risk of banks in the U.S., Europe and Japan post-financial crisis
}

\begin{abstract}
The author compares the performance, growth, asset mix, risk, operational efficiency, profitability and capital holdings of the 20 largest banks in Japan, the U.S. and Europe from 2003-2015. Total revenue for each set of banks has declined by a full $20 \%$ since 2011. European banks are in a multiyear downward spiral, evidenced by dramatic declines in market capitalization, the book value of loans and total assets, and the level of deposits. Japanese bank performance is stagnant compared to Europe and the U.S. Both Japanese and European banks are particularly challenged by persistently lower net interest margins compared to U.S. banks. The percentage of impaired, restructured or nonperforming loans soared for U.S. and European banks post-crisis, but barely rose in Japan. All banks hold more Tier 1 capital than required by the Basel III accord, which has led to profound declines in their net profit margins and return on equity. Modeling the conditional volatility of U.S., Japanese and European banks provides evidence consistent with the idea that U.S. banks continue to exhibit a more robust post-crisis recovery, while Japanese and European banks continue to experience crisis-level conditions. Any evidence that Japanese and European banks have recovered from the financial crisis is fragile at best.
\end{abstract}

Keywords: commercial banking, bank capital, regulation, risk, stock returns, profits.

JEL Classification: G18, G21.

\section{Introduction}

While U.S. banks' revenue growth, profitability and levels of balance sheet capital recovered promptly from the financial crisis of 2008-2009 (Weigand, 2013), Weigand (2015) finds that European banks continue lagging in all three categories. Factors contributing to European banks' more precarious position include the persistent economic disparity between stronger and weaker Eurozone countries and the European Central Bank's painfully slow efforts to reduce exposure to systemic risk, compared with countries such as the U.S. and the U.K. (Avadi, Arbak and de Groen, 2012). As pointed out by Gerken et al. (2013, p. 1),”... despite some apparent short-term relief ... the long-term picture remains both complex and uncertain." Other studies have questioned the very solvency of Eurozone banks (Acharya and Steffen, 2014), as potentially destabilizing developments have erupted in countries such as Portugal (Banco Espirito Santo has sought protection from its creditors), Austria, and even Germany, the Eurozone's undisputed economic leader. For example, Deutsche Bank was cited by the New York Federal Reserve Bank in 2014 as suffering from numerous problems, including "shoddy reporting and inadequate auditing and oversight" and "misstated regulatory reports" which constitute a "systemic breakdown that exposes the firm to significant operational risk" (Enrich, Strasburg and Henning, 2014, p. 1). Moreover, events such as these continue to spawn

\footnotetext{
(C) Robert A. Weigand, 2016.

Robert A. Weigand, Ph.D., Professor of Finance and Brenneman Professor of Business Strategy, Washburn University School of Business (USA)
}

unprecedented reactions that will have long-lasting implications, such as the recent legal decision that allows European countries to shift risk to depositors by reneging on deposit insurance if another systemic crisis occurs (Coppela, 2014). The need to obtain advance permission for such drastic remedies creates uncertainty over whether Europe is more focused on restoring the financial health of its banking sector or making preparations to cope with another looming crisis.

The financial condition of U.S. commercial banks contrasts sharply with that of their European counterparts. By the end of 2012, 15 of the 20 largest commercial banks in the U.S. posted recordsetting revenues, with 12 of these banks also earning record profits (Weigand, 2013). The financial performance of these banks has convinced many that they are ready to compete in a free market environment once again and require no further regulatory support. Accordingly, the U.S. Federal Reserve confirmed in the minutes of its July 2014 meeting that it will continue tapering its controversial quantitative easing program, which was terminated in October, 2014.

In this paper, I compare the financial performance, growth, asset mix, risk, operational efficiency, profitability and capital holdings of the 20 largest commercial banks in Japan, the U.S. and Europe from 2003-2015. I find that the stocks of U.S. commercial banks continued outperforming

\footnotetext{
1 It is important to note that "terminate" does not imply a complete cessation of bond buying or reducing the size of the U.S. Federal Reserve's balance sheet, which quintupled to $\$ 4.5$ trillion since 2008 . The U.S. Fed will buy new bonds when the bonds they currently own mature, with the goal of growing their balance sheet more slowly.
} 
Japanese and European banks during the 2014-2015 period, but all three sets of banks underperformed their regional stock indexes from 2014-2015. Large banks in Japan, the U.S. and Europe continue to struggle to grow their total revenue post-crisis. Total revenue has declined by a full $20 \%$ for all three sets of banks since 2011. The 20 largest banks in Europe are in a multiyear downward spiral, evidenced by dramatic declines in market capitalization, the book value of loans and total assets, and the level of deposits. Japanese bank performance is stagnant compared to Europe and the U.S. Both Japanese and European banks are particularly challenged by persistently lower net interest margins compared to U.S. banks.

Japanese and U.S. banks prefer deposits as a source of funding compared with European banks, most likely because these banks pay an average rate on deposits that is significantly lower than European banks. U.S. banks' also have an earning asset yield (EAY) that is $1.5 \%$ higher than European banks and 2.4\% higher than Japanese banks since 2011. Japanese, U.S. and European banks' loans/assets ratio has averaged between 46\%-48\% since 2009, but European banks hold a significantly higher percentage of investment and trading assets and derivative securities compared with Japanese and U.S. banks.

The mean percentage of impaired, restructured or nonperforming loans soared for U.S. and European banks post-crisis, but barely rose in Japan. While this ratio gradually declined to $4.9 \%$ for U.S. banks by 2015 , European banks continue to carry an average of $12.3 \%$ of impaired loans in their portfolios, which is approximately 3 times their precrisis average. Despite elevated levels of impaired loans, U.S. and European banks set aside a smaller percentage of assets on their balance sheets to cover likely loan losses, and expense a smaller percentage of impaired loans on their income statements compared to pre-crisis practices. Japanese, U.S. and European banks all hold more Tier 1 capital than required by the Basel III accord, although moving risky derivative positions back onto bank balance sheets in the U.S. would change these results significantly, and most likely leave U.S. banks undercapitalized.

All banks experienced profound declines in their net profit margins and return on equity during the financial crisis. Although all banks' net margins have rebounded post-crisis (between 18.8\%-25.8\%), but remain well below their pre-crisis levels. Banks' ROE shows less of a recovery post-crisis, as banks have been required to hold more shareholder equity to boost Tier 1 capital. U.S. and European banks' efficiency ratios (non-interest expense/revenue) have risen substantially post-crisis, most likely as a result of increases in regulatory requirements, while Japanese banks have achieved remarkable improvements in operating efficiency. Higher operating expenses have hampered profit generation for U.S. and European banks. U.S. banks pay a higher effective tax rate than European banks, although both sets of banks are paying lower rates since 2009. Japanese banks have paid the highest effective tax rates since 2010, averaging $31.5 \%$. European banks have higher dividend payout ratios than Japanese and U.S. banks and higher dividend yields, despite their lower profitability.

Modeling the conditional volatility of U.S., Japanese and European banks provides evidence consistent with the idea that U.S. banks continue to exhibit a more robust post-crisis recovery, while Japanese and European banks continue to experience crisis-level conditions. Any evidence that Japanese and European banks have recovered from the financial crisis is fragile at best.

This paper is organized as follows. The next section reviews the relevant literature, after which the data and empirical design are described. Empirical results follow in the next two sections, and the final section presents the paper's conclusions.

\section{Motivation and relevant literature}

The academic literature conclusively determines that larger banks enjoy a competitive advantage, which explains why the banks featured in this study are often viewed as industry bellwethers. Filbeck et al. (2011) find that size plays a significant role in a bank's ability to outperform the S\&P 500, particularly during an economic contraction. Filson and Olfati (2014) investigate banks that merge with or acquire other banks, as permitted under the Financial Services Modernization Act of 1999. These authors find that merger activity that leads to diversification into investment banking, securities brokerage and insurance activities creates value for bank shareholders.

It is also the case that changes in the regulatory environment are mainly focused on the largest banks, as they contribute disproportionately to systemic risk. The Dodd-Frank Act designates bank holding companies with $\$ 50$ billion or more in consolidated assets as systemically significant (17 of the 20 U.S. banks and all 20 of the European banks in the sample meet this criterion, shown in Table 1). Accordingly, Dodd-Frank requires large financial firms to significantly increase their balance sheet capital, which can hamper banks' efforts to maximize profits (Price, Waterhouse, Coopers, 2010). Dodd-Frank also prohibits any mergers or acquisitions that result in a new entity whose 
consolidated liabilities exceed $10 \%$ of the aggregate liabilities of all financial companies (Murphy, 2010). The new capital requirements and merger restrictions are based on the risk these banks pose to the stability of the U.S. financial system, which is determined mainly as a function of their size.

The Basel III Accord imposes even more harsher restrictions on systemically important banks, requiring them to use more of their own capital in their operations (Basel Committee on Banking Supervision, 2010). These higher capital requirements are targeted at reducing both exposure to contagion and excessive risk-taking. Jackson et al (1999), Santos (2001), Stolz (2002), and VanHoose $(2006,2007)$ find that higher capital standards lead to higher capital ratios, and also act as constraints that are likely to reduce total lending. Accordingly, banks' balance sheets reflect this substitution of alternative assets for loans. The shift to alternative assets is also being driven by global private sector deleveraging, which has further reduced the rate of loan growth (Keen, 2009).

The larger banks in both the U.S. and Europe are usually referred to as "Too Big to Fail" (TBTF) due to their systemic importance. Demirguc-Kunt and Huizinga (2010) find that the TBTF banks are more costly to bail out, and many believe that these banks exploit the moral hazard problem of regulators being too quick to rush to their aid when they assume more risk than they can manage. For example, European banks have invested hundreds of billions of Euros in the long-dated sovereign bonds of other European nations. Known as the "carry trade", these investments are designed to profit from the spread between the low-cost short-term funding supported by the zero interest rate polices of the world's major central banks and the higher yields of the bonds of economically-troubled nations such as Greece, Ireland, Portugal, Spain and Italy. The carry trade is essentially a bet that Eurozone countries will converge economically, resulting in a narrowing of the spread as the yields of sovereign bonds fall. The long-awaited economic convergence has not materialized, however, and as the spreads have widened further, European banks have actually increased their holdings of these risky positions (Acharya and Steffan, 2014). This massive carry trade exposure has most likely led to an increase in systemic risk, as it is essentially a network of overleveraged nations holding each other's bonds backed by nothing more than verbal assurance that they will not default. Correa, Lee, Sapriza and Suarez (2014) investigate this issue and confirm that the key factor allowing banks to maintain and expand exposure to these risky positions are the implied government guarantees backing these bonds.
Buttiglione, Lane, Reichlin and Reinhart (2014) study how the dynamics of debt accumulation influences macroeconomic conditions, essentially extending the "financial instability hypothesis" originally described by Fisher (1933) and further developed by Minsky (1977). The essence of their argument is that high debt levels increase vulnerability to the risk of a financial crisis (Gourinchas and Obstfeld, 2012; and Catão and Milesi-Ferretti, 2013). Deleveraging during the late stage of an economic contraction and the early phase of the ensuing economic recovery, therefore, contributes to macroeconomic stability. Buttiglione et al. (2014, pp. 1-2) reach several disturbing conclusions, however: “... the world has not begun to delever and the global debt-to-GDP ratio is still growing" and "... the global capacity to take on [additional] debt has been reduced through the combination of slower expansion in real output and lower inflation". Writing for the Center for European Policy Studies, Ayadi, Arbak and de Groen (2012) reach similar conclusions, finding that EU banks remain undercapitalized and excessively reliant on an unstable funding model, large derivative positions, and additional concentration among large banks that has decreased competition and increased systemic risk.

Baron and Xong (2014) also document an inverse relation between excessive debt accumulation and financial stability. These authors find that rapid credit expansion is supported by over-optimism that causes investors to underprice "crash risk" in global equity markets. Their conclusions are consistent with the idea that the zero interest rate and quantitative easing policies of world central banks fuel instability via "financial repression," which causes investors to chase risk and bid up the prices of riskier assets, thus reducing their future expected returns and compressing risk premia, with the risk of a stock market crash being one of the primary risks that is less than fully priced.

Schildback, Wenzel and Speyer (2013, p. 1) describe the growth in revenues, profits and loans of banks in the U.S. and Europe as "an ocean apart". These authors specifically cite the U.S. Federal Reserve's faster regulatory response to the crisis and more aggressive intervention as factors promoting the superior recovery of U.S. banks. They describe the European banking regulatory framework as "patchwork" vs. that of the U.S., with these weaker regulations allowing Eurozone banks to write down only $\$ 500$ million of loans, while U.S. banks' total writedowns have already exceeded $\$ 1$ trillion. Schildback et al conclude that the lack of profitability of Eurozone banks is unsustainable, and that these banks are not yet close to earning their cost 
of capital. These factors have had a profoundly negative impact on the European economy because the role of banks in providing credit to the private and public sectors is more important in Europe, as the shadow banking system in the U.S. has provided an alternative source of credit vs. the traditional banking sector since the 1990s. These authors conclude that the U.S. is fundamentally different from Europe due to factors such as: an aggressive central bank with a much broader mandate than the ECB; the U.S. Dollar is the global currency standard vs. the Euro; world financial markets doubt the solvency of some European governments compared with the U.S. government; the U.S. has a more flexible labor market; and the U.S. economy is less dependent on weaker trading partners.

\section{Data and descriptive statistics}

Data for this study are obtained from Standard \& Poor's Capital IQ (CIQ) and the Federal Reserve Economic Database (FRED). The 20 largest financial services entities designated as "Banks, Primary" (in terms of market capitalization) as of year-end 2015 headquartered in Japan, Europe and the U.S. are identified using CIQ (Deutsche Bank is eliminated from the sample due to its unique liquidity problems related to derivative contracts at the time of this writing). Japanese and European financial data are converted to U.S. dollars using historical currency rates for the relevant fiscal year. All metrics reported below are based on either aggregate data or market capitalization-weighted averages for all 20 banks.

The identity of the banks in the sample and descriptive statistics are presented as Tables 1, 2 and 3. The median market capitalization of the U.S. banks is $\$ 14.8$ billion; they hold median total assets of over $\$ 134$ billion, median total deposits of over $\$ 99$ billion, and median total loans of over $\$ 89$ billion.

Table 1. Descriptive Statistics. Largest 20 U.S. Banks (in terms of market capitalization) designated as "Banks, Primary" in S\&P's Capital IQ database as of year-end 2015 (values in millions)

\begin{tabular}{|c|c|c|c|c|}
\hline & Market & Total & Total & Total \\
\hline Bank & Capitalization & Assets & Deposits & Loans \\
\hline JPMorgan Chase \& Co. & $\$ 245.980$ & $\$ 2.466 .096$ & $\$ 1.330 .958$ & $\$ 868.782$ \\
\hline Wells Fargo \& Company & $\$ 228.715$ & $\$ 1.889 .235$ & $\$ 1.245 .473$ & $\$ 945.493$ \\
\hline Bank of America Corporation & $\$ 164.603$ & $\$ 2.186 .609$ & $\$ 1.216 .091$ & $\$ 891.316$ \\
\hline Citigroup Inc. & $\$ 143.177$ & $\$ 1.818 .771$ & $\$ 937.852$ & $\$ 621.211$ \\
\hline U.S. Bancorp & $\$ 74.794$ & $\$ 438.463$ & $\$ 317.590$ & $\$ 264.715$ \\
\hline The PNC Financial Services Group, Inc. & $\$ 44.925$ & $\$ 361.335$ & $\$ 249.778$ & $\$ 206.371$ \\
\hline BB\&T Corporation & $\$ 31.676$ & $\$ 221.859$ & $\$ 159.238$ & $\$ 140.719$ \\
\hline SunTrust Banks, Inc. & $\$ 22.650$ & $\$ 198.892$ & $\$ 152.751$ & $\$ 139.882$ \\
\hline M\&T Bank Corporation & $\$ 18.472$ & $\$ 123.821$ & $\$ 94.650$ & $\$ 86.950$ \\
\hline Fifth Third Bancorp & $\$ 15.856$ & $\$ 143.625$ & $\$ 101.871$ & $\$ 92.610$ \\
\hline KeyCorp. & $\$ 13.722$ & $\$ 101.150$ & $\$ 75.325$ & $\$ 61.244$ \\
\hline Citizens Financial Group, Inc. & $\$ 13.247$ & $\$ 145.183$ & $\$ 106.257$ & $\$ 102.305$ \\
\hline Regions Financial Corporation & $\$ 12.966$ & $\$ 126.212$ & $\$ 97.245$ & $\$ 80.551$ \\
\hline First Republic Bank & $\$ 11.763$ & $\$ 64.730$ & $\$ 51.161$ & $\$ 47.329$ \\
\hline Huntington Bancshares Incorporated & $\$ 11.034$ & $\$ 73.954$ & $\$ 55.043$ & $\$ 51.920$ \\
\hline Comerica Incorporated & $\$ 8.518$ & $\$ 24.313$ & $\$ 20.689$ & $\$ 9.423$ \\
\hline CIT Group Inc. & $\$ 7.460$ & $\$ 66.700$ & $\$ 32.879$ & $\$ 30.057$ \\
\hline Signature Bank & $\$ 6.620$ & $\$ 36.547$ & $\$ 29.579$ & $\$ 26.490$ \\
\hline Zions Bancorporation & $\$ 6.508$ & $\$ 59.643$ & $\$ 50.271$ & $\$ 41.893$ \\
\hline SVB Financial Group & $\$ 6.187$ & $\$ 43.133$ & $\$ 37.597$ & $\$ 18.589$ \\
\hline mean 2015 & $\$ 54.444$ & $\$ 529.514$ & $\$ 318.115$ & $\$ 236.393$ \\
\hline median 2015 & $\$ 14.789$ & $\$ 134.919$ & $\$ 99.558$ & $\$ 89.780$ \\
\hline maximum 2015 & $\$ 245.980$ & $\$ 2.466 .096$ & $\$ 1.330 .958$ & $\$ 945.493$ \\
\hline minimum 2015 & $\$ 6.187$ & $\$ 24.313$ & $\$ 20.689$ & $\$ 9.423$ \\
\hline mean 2013 & $\$ 28.079$ & $\$ 177.734$ & $\$ 126.922$ & $\$ 102.404$ \\
\hline median 2013 & $\$ 9.103$ & $\$ 64.561$ & $\$ 51.549$ & $\$ 46.368$ \\
\hline maximum 2013 & $\$ 267.220$ & $\$ 1.598 .874$ & $\$ 1.118 .577$ & $\$ 815.841$ \\
\hline minimum 2013 & $\$ 4.128$ & $\$ 23.032$ & $\$ 13.939$ & $\$ 9.423$ \\
\hline growth in mean since 2013 & $93.9 \%$ & $197.9 \%$ & $150.6 \%$ & $130.8 \%$ \\
\hline growth in median since 2013 & $62.5 \%$ & $109.0 \%$ & $93.1 \%$ & $93.6 \%$ \\
\hline growth in maximum since 2013 & $-7.9 \%$ & $54.2 \%$ & $19.0 \%$ & $15.9 \%$ \\
\hline growth in minimum since 2013 & $49.9 \%$ & $5.6 \%$ & $48.4 \%$ & $0.0 \%$ \\
\hline
\end{tabular}


The greater concentration of banking activity in larger banks in Europe, which is often cited as the primary hurdle to reducing systemic risk, is reflected in their descriptive statistics. The median market capitalization of the European banks is twice as large at $\$ 28.4$ billion; they hold median assets of $\$ 771$ billion, median total deposits of $\$ 369$ billion and median total loans of $\$ 379$ billion, which are 5.7, 3.7, and 4.2 times as large as the respective medians for the sample of U.S. banks.

Table 2. Descriptive Statistics. Largest 20 European Banks (in terms of market capitalization) designated as "Banks, Primary" in S\&P's Capital IQ database as of year-end 2015 (values in millions)

\begin{tabular}{|c|c|c|c|c|}
\hline & Market & Total & Total & Total \\
\hline Bank & Capitalization & Assets & Deposits & Loans \\
\hline HSBC Holdings plc & $\$ 152.806$ & $\$ 2.608 .149$ & $\$ 1.360 .858$ & $\$ 979.868$ \\
\hline BNP Paribas SA & $\$ 68.605$ & $\$ 2.412 .115$ & $\$ 808.339$ & $\$ 800.322$ \\
\hline Banco Santander, S.A. & $\$ 63.815$ & $\$ 1.491 .372$ & $\$ 607.400$ & $\$ 936.063$ \\
\hline Lloyds Banking Group plc & $\$ 46.429$ & $\$ 1.127 .676$ & $\$ 581.287$ & $\$ 635.594$ \\
\hline Nordea Bank AB (publ) & $\$ 41.728$ & $\$ 745.445$ & $\$ 267.113$ & $\$ 356.952$ \\
\hline Banco Bilbao Vizcaya Argentaria, S.A. & $\$ 39.119$ & $\$ 828.519$ & $\$ 507.841$ & $\$ 485.307$ \\
\hline Intesa Sanpaolo S.p.A. & $\$ 37.374$ & $\$ 796.593$ & $\$ 324.390$ & $\$ 401.189$ \\
\hline Barclays PLC & $\$ 36.550$ & $\$ 1.796 .452$ & $\$ 623.397$ & $\$ 629.415$ \\
\hline Societe Generale Group & $\$ 29.349$ & $\$ 1.621 .681$ & $\$ 522.508$ & $\$ 434.784$ \\
\hline Credit Agricole S.A. & $\$ 28.509$ & $\$ 1.757 .211$ & $\$ 677.704$ & $\$ 448.427$ \\
\hline Danske Bank A/S & $\$ 28.235$ & $\$ 519.931$ & $\$ 156.980$ & $\$ 251.510$ \\
\hline Standard Chartered PLC & $\$ 27.456$ & $\$ 660.989$ & $\$ 413.113$ & $\$ 334.842$ \\
\hline Svenska Handelsbanken AB & $\$ 26.774$ & $\$ 357.561$ & $\$ 143.451$ & $\$ 240.236$ \\
\hline The Royal Bank of Scotland Group plc & $\$ 26.322$ & $\$ 1.198,657$ & $\$ 514.622$ & $\$ 434.067$ \\
\hline Swedbank AB (publ) & $\$ 26.003$ & $\$ 292.124$ & $\$ 110.473$ & $\$ 182.965$ \\
\hline KBC Group NV & $\$ 25.447$ & $\$ 295.054$ & $\$ 187.614$ & $\$ 162.839$ \\
\hline Skandinaviska Enskilda Banken AB & $\$ 22.613$ & $\$ 315.875$ & $\$ 130.843$ & $\$ 169.858$ \\
\hline DNB ASA & $\$ 22.429$ & $\$ 318.341$ & $\$ 114.804$ & $\$ 206.812$ \\
\hline Allied Irish Banks, p.I.c. & $\$ 17.434$ & $\$ 108.154$ & $\$ 67.903$ & $\$ 68.260$ \\
\hline Natixis & $\$ 15.549$ & $\$ 594.016$ & $\$ 149,522$ & $\$ 211.826$ \\
\hline mean 2015 & $\$ 39.127$ & $\$ 992.296$ & $\$ 413.508$ & $\$ 418.557$ \\
\hline median 2015 & $\$ 28.372$ & $\$ 771.019$ & $\$ 368.752$ & $\$ 379.070$ \\
\hline maximum 2015 & $\$ 152.806$ & $\$ 2.608 .149$ & $\$ 1.360 .858$ & $\$ 979.868$ \\
\hline minimum 2015 & $\$ 15.549$ & $\$ 108.154$ & $\$ 67.903$ & $\$ 68.260$ \\
\hline mean 2013 & $\$ 96.098$ & $\$ 1.386 .332$ & $\$ 570.561$ & $\$ 715.273$ \\
\hline median 2013 & $\$ 52.744$ & $\$ 1.099 .522$ & $\$ 481.374$ & $\$ 499.466$ \\
\hline maximum 2013 & $\$ 365.717$ & $\$ 3.273 .485$ & $\$ 1.455 .526$ & $\$ 1.843 .550$ \\
\hline minimum 2013 & $\$ 12,000$ & $\$ 117,734$ & $\$ 59,884$ & $\$ 66,147$ \\
\hline growth in mean since 2013 & $-59.3 \%$ & $-28.4 \%$ & $-27.5 \%$ & $-41.5 \%$ \\
\hline growth in median since 2013 & $-46.2 \%$ & $-29.9 \%$ & $-23.4 \%$ & $-24.1 \%$ \\
\hline growth in maximum since 2013 & $-58.2 \%$ & $-20.3 \%$ & $-6.5 \%$ & $-46.8 \%$ \\
\hline growth in minimum since 2013 & $29.6 \%$ & $-8.1 \%$ & $13.4 \%$ & $3.2 \%$ \\
\hline
\end{tabular}

Japan's descriptive statistics (Table 3) show an even greater concentration of banking activity. The three largest banks, Mitsubishi, Sumitomo and Mizuho, account for $67 \%$ of the total loans of Japan's largest
20 banks and $70 \%$ of total deposits, which implies an even greater potential for transmission of systemic risk shocks within the Japanese banking system.

Table 3. Descriptive Statistics. Largest 20 Japanese Banks (in terms of market capitalization) designated as "Banks, Primary" in S\&P's Capital IQ database as of year-end 2015 (values in millions)

\begin{tabular}{|l|c|c|c|c|}
\hline & Market & Total & Total & Total \\
\hline \multicolumn{1}{|c|}{ Bank } & Capitalization & Assets & Deposits & Loans \\
\hline Mitsubishi UFJ Financial Group, Inc. & $\$ 68,373$ & $\$ 2,903,685$ & $\$ 1,672,084$ & $\$ 1,050,354$ \\
\hline Sumitomo Mitsui Financial Group, Inc. & $\$ 45,508$ & $\$ 1,766,116$ & $\$ 1,175,857$ & $\$ 758,999$ \\
\hline Mizuho Financial Group, Inc. & $\$ 41,725$ & $\$ 1,925,270$ & $\$ 1,169,552$ & $\$ 709,317$ \\
\hline Sumitomo Mitsui Trust Holdings, Inc. & $\$ 12,189$ & $\$ 580,777$ & $\$ 374,094$ & $\$ 269,718$ \\
\hline Resona Holdings, Inc. & $\$ 9,620$ & $\$ 451,648$ & $\$ 385,014$ & $\$ 264,820$ \\
\hline
\end{tabular}


Table 3. Descriptive Statistics. Largest 20 Japanese Banks (in terms of market capitalization) designated as "Banks, Primary" in S\&P's Capital IQ database as of year-end 2015 (values in millions) (cont.)

\begin{tabular}{|c|c|c|c|c|}
\hline Suruga Bank Ltd. & $\$ 5,636$ & $\$ 43,021$ & $\$ 39,741$ & $\$ 30,320$ \\
\hline The Shizuoka Bank, Ltd. & $\$ 4,994$ & $\$ 108,739$ & $\$ 89,439$ & $\$ 76,115$ \\
\hline The Chiba Bank, Ltd. & $\$ 4,830$ & $\$ 134,767$ & $\$ 113,011$ & $\$ 86,789$ \\
\hline Mebuki Financial Group, Inc. & $\$ 4,354$ & $\$ 91,474$ & $\$ 79,582$ & $\$ 56,498$ \\
\hline Shinsei Bank, Limited & $\$ 4,082$ & $\$ 90,271$ & $\$ 56,522$ & $\$ 43,589$ \\
\hline Aozora Bank, Ltd. & $\$ 3,728$ & $\$ 44,971$ & $\$ 28,049$ & $\$ 23,565$ \\
\hline The Bank of Kyoto, Ltd. & $\$ 2,708$ & $\$ 79,390$ & $\$ 69,820$ & $\$ 45,425$ \\
\hline The Hachijuni Bank, Ltd. & $\$ 2,661$ & $\$ 81,657$ & $\$ 67,635$ & $\$ 45,315$ \\
\hline The Hiroshima Bank, Ltd. & $\$ 2,622$ & $\$ 83,512$ & $\$ 72,145$ & $\$ 51,503$ \\
\hline The Chugoku Bank, Limited & $\$ 2,459$ & $\$ 77,499$ & $\$ 61,777$ & $\$ 39,868$ \\
\hline The Gunma Bank, Ltd. & $\$ 2,073$ & $\$ 24,313$ & $\$ 20,689$ & $\$ 9,423$ \\
\hline The lyo Bank, Ltd. & $\$ 1,873$ & $\$ 64,420$ & $\$ 52,325$ & $\$ 40,156$ \\
\hline Hokuhoku Financial Group, Inc. & $\$ 1,837$ & $\$ 114,713$ & $\$ 103,169$ & $\$ 73,926$ \\
\hline The Awa Bank, Limited & $\$ 1,489$ & $\$ 30,550$ & $\$ 26,751$ & $\$ 16,797$ \\
\hline The 77 Bank, Ltd. & $\$ 1,616$ & $\$ 82,692$ & $\$ 75,430$ & $\$ 41,508$ \\
\hline mean 2015 & $\$ 11,219$ & $\$ 438,974$ & $\$ 286,634$ & $\$ 186,700$ \\
\hline median 2015 & $\$ 3,905$ & $\$ 86,892$ & $\$ 73,787$ & $\$ 48,464$ \\
\hline maximum 2015 & $\$ 68,373$ & $\$ 2,903,685$ & $\$ 1,672,084$ & $\$ 1,050,354$ \\
\hline minimum 2015 & $\$ 1,489$ & $\$ 24,313$ & $\$ 20,689$ & $\$ 9,423$ \\
\hline mean 2013 & $\$ 15,661$ & $\$ 397,546$ & $\$ 268,780$ & $\$ 216,886$ \\
\hline median 2013 & $\$ 3,306$ & $\$ 87,739$ & $\$ 75,339$ & $\$ 54,579$ \\
\hline maximum 2013 & $\$ 93,462$ & $\$ 2,447,681$ & $\$ 1,573,435$ & $\$ 1,054,528$ \\
\hline minimum 2013 & $\$ 1,146$ & $\$ 30,462$ & $\$ 26,693$ & $\$ 29,404$ \\
\hline growth in mean since 2013 & $-28.4 \%$ & $10.4 \%$ & $6.6 \%$ & $-13.9 \%$ \\
\hline growth in median since 2013 & $18.1 \%$ & $-1.0 \%$ & $-2.1 \%$ & $-11.2 \%$ \\
\hline growth in maximum since 2013 & $-26.8 \%$ & $18.6 \%$ & $6.3 \%$ & $-0.4 \%$ \\
\hline growth in minimum since 2013 & $29.9 \%$ & $-20.2 \%$ & $-22.5 \%$ & $-68.0 \%$ \\
\hline
\end{tabular}

The main theme of this analysis is illustrated by the results presented in the lower panels of Tables 1,2 and 3. Growth in the mean, median, maximum and minimum values for market capitalization, assets, deposits and loans from 2013-2015 is shown for each sample. With the exception of the maximum market capitalization and minimum total loans, all descriptive statistic values for U.S. banks are significantly larger in each category since 2013 . The comparison with European banks is striking. The lower panel of Table 2 shows that European banks have lower values in each category since 2013, with the exception of the minimum market capitalization, deposits and loans. European banks' maximum market capitalization has declined by $58 \%$ in 2 years, along with their maximum assets $(-20 \%)$, maximum deposits $(-6.5 \%)$ and maximum loans $(-47 \%)$. Median values for all descriptive statistics are 23\%-46\% lower since 2013. Although the results below will show that both sets of banks face challenges in terms of future growth, Table 2 illustrates the extent to which European banks' growth problems are more severe, especially in light of the languishing problems with the quality of their loan portfolios compared with U.S. banks. Table 3 shows that Japan has remained stagnant compared to the U.S. and Europe since 2013, although average total loans have decreased by $14 \%$, and the mean and maximum market capitalization of the sample of Japanese banks have declined by $28 \%$ and $27 \%$, respectively.

\section{Stock returns and revenue sources}

Figure 1 depicts the monthly compound stock returns for the sample of U.S., European and Japanese banks beginning in March 2011 and ending in September 2016. U.S. banks' total return of $45 \%$ far exceeds the $10 \%$ return for Japanese banks and the $-22 \%$ mean return for European banks, although it is important to note that all three bank stock indexes underperformed their home country or regional stock indexes over the same period. These results are consistent with the idea that investors have a less favorable view of the future prospects of the global banking sector than other sectors. In particular, the lower returns of the Euronext 100 and the European banks correspond to the continent's weaker economic conditions, as the Eurozone has been in danger of entering its third recession in 8 years as of late 2016. It is interesting to note the change in investors' attitudes regarding the banking sectors 
in both the U.S. and Europe since 2013. Weigand (2015) reports that for the 5-year period ending in December 2013, the stock returns of the major commercial banks in the U.S. and Europe significantly outperformed their regional stock indexes, suggesting that each region's financial sector was viewed more favorably by equity investors compared with other sectors just 2 years ago. The relatively low stock returns of the 20 largest banks in each region indicate that investors' attitudes regarding bank stocks have deteriorated significantly since 2013 .

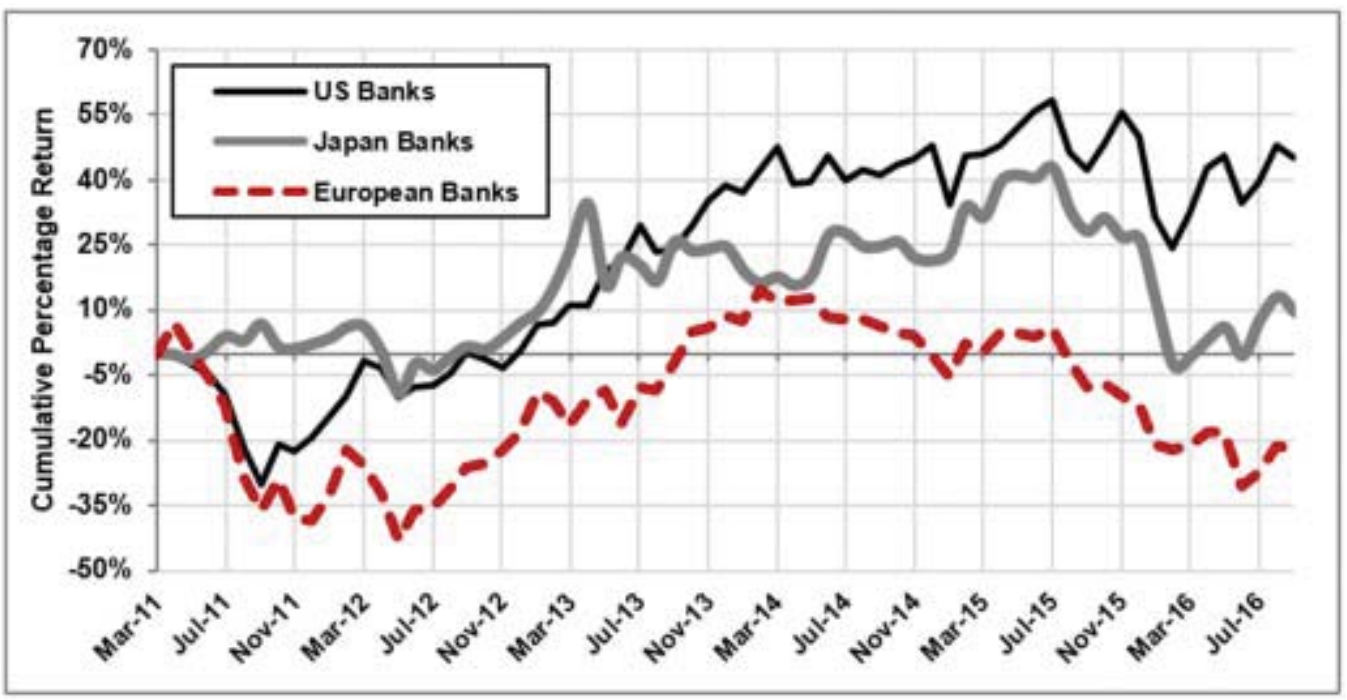

Fig. 1. Compound Stock Returns to U.S., European and Japanese Banks, 2011-2016

Figure 2 and Table 4 depict the cumulative growth in total revenues before loan losses for the three sets of banks from 2003-2015. The large number of arranged mergers between weaker and stronger U.S. banks immediately following the financial crisis in 2009 makes it difficult to compare organic revenue growth among Japan, Europe and the U.S., but several conclusions are unmistakable nonetheless. Japan's long period of stagnation is once again evident, with total revenue growth over the 12-year period of less than 20\%. For both U.S. and European banks, growth in total revenue peaked in 2011, and has trended lower for the next 4 years. Interestingly, for all three bank indexes, total revenue in 2015 is 20\% lower than in 2011. The multiyear decline in total revenue confirms investors' concerns regarding these banks' future prospects as both companies and investments. Post-financial crisis, banking activities in developed regions such as Japan, the U.S. and Europe have been in a protracted decline. Next I examine the traditional sources of revenue for the three sets of banks.

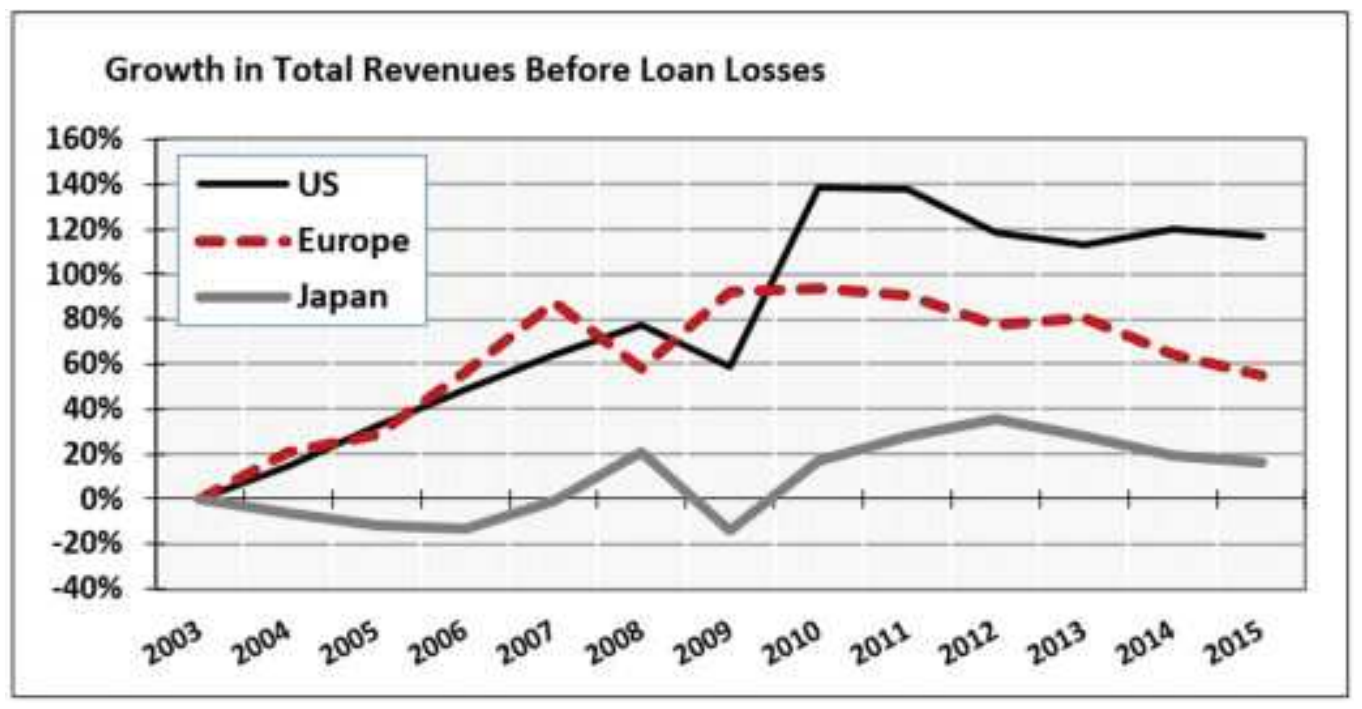

Fig. 2. Growth in Total Revenues Before Loan Losses for U.S., European and Japanese Banks, 2003-2015

Table 4 also shows the capitalization-weighted mean ratio of net interest income to total revenue and net interest margin (NIM) from 2003-2015. U.S. banks earned between $54 \%-60 \%$ of their total revenue from interest income each year, while European banks earned between 44\%-62\%. The average for both sets of banks has remained stable post-financial crisis. U.S. and European banks 
nearly identical percentages of their total revenues from interest income post-crisis (55\% and 58\%, respectively, as of year-end 2015). Although all three sets of banks earned similar percentages of revenue from interest-based sources in 2009-2010, Japan has experienced the greatest decline, with an interest to revenue ratio of less than $42 \%$ in 2015.

Table 4.Compound Revenue Growth, Net Interest Income and Net Interest Margin

\begin{tabular}{|c|c|c|c|c|c|c|c|c|c|c|c|c|}
\hline \multirow[b]{2}{*}{ Year } & \multicolumn{3}{|c|}{$\begin{array}{c}\text { Total Revenue Before } \\
\text { Loan Losses ( } \$ \mathrm{~mm} \text { ) }\end{array}$} & \multicolumn{3}{|c|}{$\begin{array}{l}\text { Cumulative Revenue } \\
\text { Growth Since } 2003\end{array}$} & \multicolumn{3}{|c|}{$\begin{array}{l}\text { Net Interest Income } \\
\text { to Total Revenue }\end{array}$} & \multicolumn{3}{|c|}{$\begin{array}{c}\text { Net Interest } \\
\text { Margin }\end{array}$} \\
\hline & us & Europe & Japan & us & Europe & Japan & US & Europe & Japan & US & Europe & Japan \\
\hline 2003 & $\$ 261,505$ & $\$ 228,737$ & $\$ 109,837$ & $0.0 \%$ & $0.0 \%$ & $0.0 \%$ & $59.7 \%$ & $51.2 \%$ & $46.6 \%$ & $3.8 \%$ & $2.0 \%$ & $0.9 \%$ \\
\hline 2004 & $\$ 316,054$ & $\$ 263,104$ & $\$ 103,236$ & $15.0 \%$ & $20.9 \%$ & $-6.0 \%$ & $58.3 \%$ & $50.2 \%$ & $46.5 \%$ & $3.6 \%$ & $1.7 \%$ & $0.8 \%$ \\
\hline 2005 & $\$ 335,820$ & $\$ 295,062$ & $\$ 101,468$ & $32.3 \%$ & $28.4 \%$ & $-11.7 \%$ & $57.3 \%$ & $46.5 \%$ & $48.8 \%$ & $3.2 \%$ & $1.4 \%$ & $0.9 \%$ \\
\hline 2006 & $\$ 409,405$ & $\$ 326,466$ & $\$ 116,275$ & $48.4 \%$ & $56.6 \%$ & $-13.2 \%$ & $57.4 \%$ & $44.3 \%$ & $48.0 \%$ & $3.1 \%$ & $1.1 \%$ & $0.9 \%$ \\
\hline 2007 & $\$ 491,091$ & $\$ 352,357$ & $\$ 141,138$ & $64.2 \%$ & $87.8 \%$ & $-0.5 \%$ & $57.0 \%$ & $44.3 \%$ & $47.0 \%$ & $3.0 \%$ & $1.2 \%$ & $0.9 \%$ \\
\hline 2008 & $\$ 412,419$ & $\$ 315,433$ & $\$ 100,494$ & $77.2 \%$ & $57.7 \%$ & $20.8 \%$ & $54.9 \%$ & $61.6 \%$ & $68.8 \%$ & $3.5 \%$ & $1.3 \%$ & $0.8 \%$ \\
\hline 2009 & $\$ 501,517$ & $\$ 474,808$ & $\$ 136,311$ & $58.6 \%$ & $91.8 \%$ & $-14.0 \%$ & $54.4 \%$ & $58.5 \%$ & $51.6 \%$ & $3.3 \%$ & $1.1 \%$ & $0.9 \%$ \\
\hline 2010 & $\$ 506,525$ & $\$ 472,433$ & $\$ 149,154$ & $138.8 \%$ & $93.7 \%$ & $16.6 \%$ & $57.9 \%$ & $57.4 \%$ & $50.8 \%$ & $3.4 \%$ & $1.2 \%$ & $0.9 \%$ \\
\hline 2011 & $\$ 497,584$ & $\$ 433,842$ & $\$ 158,471$ & $137.6 \%$ & $90.3 \%$ & $27.6 \%$ & $54.4 \%$ & $57.6 \%$ & $48.1 \%$ & $3.3 \%$ & $1.3 \%$ & $0.8 \%$ \\
\hline 2012 & $\$ 464,192$ & $\$ 424,359$ & $\$ 149,438$ & $118.2 \%$ & $77.5 \%$ & $35.6 \%$ & $55.6 \%$ & $57.9 \%$ & $44.7 \%$ & $3.0 \%$ & $1.1 \%$ & $0.8 \%$ \\
\hline 2013 & $\$ 471,597$ & $\$ 437,776$ & $\$ 139,445$ & $113.4 \%$ & $80.3 \%$ & $27.9 \%$ & $56.1 \%$ & $54.9 \%$ & $45.3 \%$ & $2.9 \%$ & $1.1 \%$ & $0.8 \%$ \\
\hline 2014 & $\$ 429,973$ & $\$ 431,464$ & $\$ 135,685$ & $120.1 \%$ & $64.4 \%$ & $19.3 \%$ & $53.8 \%$ & $57.7 \%$ & $42.0 \%$ & $2.8 \%$ & $1.4 \%$ & $0.5 \%$ \\
\hline 2015 & $\$ 405,897$ & $\$ 431,609$ & $\$ 140,808$ & $117.0 \%$ & $55.2 \%$ & $16.1 \%$ & $55.0 \%$ & $57.5 \%$ & $41.8 \%$ & $2.7 \%$ & $1.3 \%$ & $0.7 \%$ \\
\hline
\end{tabular}

I further investigate reasons for the different rates of revenue growth by examining the NIM for both sets of banks from 2003-2015. Table 4 shows that U.S. banks' mean NIM has trended lower since 2010, while European banks' mean NIM has trended slightly higher. These differential trends do not tell the full story, however. U.S. banks' NIM has averaged between $2.7 \%-3.8 \%$ since 2003 , so their 2015 NIM of $2.7 \%$ is merely at the low end of their normal range over the past 12 years. European banks' NIM has averaged between 1.1\%-2.0\% over the same period, with their 2015 value of $1.3 \%$ also representing the low end of their historical range. The impact of these NIMs on the each set of banks' profit potential (examined in greater detail in Table 7 below) is profoundly important, as illustrated by the following calculation. Table 3 shows that $55.0 \%$ of U.S. banks' total revenue of $\$ 405.9$ billion in 2015 was generated by interest from various lending activities, which equates to $\$ 10.96$ billion of gross profit (calculated as revenue of $\$ 405.9$ billion $\times$ a mean NIM of 2.7\%). European banks' generated a remarkably similar total revenue of $\$ 431.6$ billion in 2015 , which equates to only $\$ 5.6$ billion of gross profit, however (calculated as total revenue of $\$ 431.6$ billion $\times$ a mean NIM of $1.3 \%$ ). Therefore, despite having almost twice the dollar value of total loans outstanding (see Tables 1 and 2), European banks generate substantially lower revenues on their lending portfolios compared with U.S. banks. This accounts for much of the superior long-term revenue growth of U.S. banks reported in Figure 2 and Table 3. Japan's mean NIM is remarkably lower than both that of U.S. and Europe. The mean NIM of the sample of Japanese banks has never exceeded 1.0\% over the past 12 years, which accounts for much of the stagnation in their revenue growth.

Figure 3 depicts key benchmark interest rates in Japan, the U.S. and Europe from October 2011 through mid-October of 2016 (the yields on a 10year Japanese government bond, 10-year U.S. Treasury note and a 10-year Eurozone government bond, respectively). The difference in the levels and trends of these key interest rates helps to explain why European banks' mean NIM is less than half as large as the mean NIM of U.S. banks. Until the onset of the financial crisis in the fall of 2007, the yield on these instruments was virtually identical, as would be expected in fully globalized financial markets. Beginning in 2008, however, as the U.S. Federal Reserve and European Central Bank (ECB) began reducing key short-term interest rates (which eventually evolved into their bond-buying Quantitative Easing programs), the yield on the 10year Eurobond has tracked profoundly lower than the yield on a 10-year Treasury note, with a yield spread difference occasionally approaching 250 basis points. These unnaturally low interest rates severely constrain European banks' ability to charge interest rates on loans that would allow them to earn profits that make them legitimate global competitors to U.S. banks.

The Bank of Japan (BOJ) has implemented similar low interest rate policies for a considerably longer period of time, thus their benchmark interest rates have been substantially lower than either the U.S. or Europe until recently. Moreover, notice how the Japanese and European yields have been pushed into negative territory by the overly-aggressive 
Quantitative Easing policies of the JOB and ECB. How banks are expected to generate revenues and earn profits when benchmark interest rates are forced below zero by central bank bureaucrats remains a key question that continues to go unanswered at the time of this writing.

Summarizing the results of this section, I find that:

The stocks of U.S. commercial banks, which earned higher returns than European banks from 2009-2013 (Weigand, 2015), continued outperforming Japanese and European banks during the 2014-2015 period. Unlike the 2009-2013 period, however, when banks outperformed their home stock market indexes, Japanese, U.S. and European banks underperformed the Nikkei 225, S\&P 500 and Euronext 100, respectively, 2014-2015.

- European banks' key performance metrics have declined dramatically in recent years. The largest market capitalization of any European bank has declined by 58\% from 2013-2015, with the maximum book value of loans declining by $47 \%$, the maximum book value of assets declining by $20 \%$, and the maximum level of deposits declining by $6.5 \%$ over the same period. The 20 largest banks in Europe are in a multiyear downward spiral, as measured by stock returns, revenues, loan volume, asset size and deposited funds. Japanese banks' market capitalization, loans, assets and deposits are largely unchanged over the 2013-2015 period.

- Large U.S. and European commercial banks continue to struggle in their attempts to grow their total revenue post-crisis. The decline in total revenue reported by Weigand (2015) for both sets of banks from 2010-2013 continued in the 2014-2015 period. Total revenue for Japanese, U.S. and European banks has declined by $20 \%$ since 2011 .

- While the 20 largest U.S. and European banks generate similar levels of aggregate total revenue (\$406 billion and $\$ 432$ billion, respectively), the persistently lower net interest margin generated by Japanese and European banks results in these banks earning substantially lower gross profits from their lending and other interest-earning activities compared with U.S. banks.

\section{Loan quality, trading assets, deposits and bank capital.}

In this section, I examine the major asset categories and liability exposure of Japanese, U.S. and European banks with the purpose of assessing the strength of banks' balance sheets pre- and postfinancial crisis. Table 5 depicts banks' major funding source, deposits, relative to total assets from 2003-2015. From 2003-2010, U.S. banks' deposits/assets ratio was stable in a range between $51 \%-55 \%$, after which the ratio begins increasing, reaching a high of $63 \%$ in 2015 . U.S. banks are clearly relying more heavily on deposits as a source of capital in the post-financial crisis period. Japanese banks' deposits to assets ratio ranges from 68\%-71\% over the same period. European banks' mean deposits/assets ratio displays a similar trend in the post-crisis years, rising from $42 \%$ in 2010 to $47 \%$ by 2015 . Japanese and U.S. banks rely more heavily on deposits as a funding source than European banks.

Table 5. Bank Deposits, Interest Paid on Deposits, and Charges and Fees on Deposits

\begin{tabular}{cccccccccccccc} 
& \multicolumn{3}{c}{$\begin{array}{c}\text { Deposits to } \\
\end{array}$} & \multicolumn{3}{c}{ Total Assets } & \multicolumn{4}{c}{$\begin{array}{c}\text { Interest on Deposits to } \\
\text { Interest-Bearing Deposits }\end{array}$} & \multicolumn{2}{c}{$\begin{array}{c}\text { Deposit Charges and } \\
\text { Fees to Total Revenue }\end{array}$} & \multicolumn{2}{c}{$\begin{array}{c}\text { Earning } \\
\text { Asset Yield }\end{array}$} \\
\hline Year & US & Europe & Japan & US & Europe & Japan & US & Europe & Japan & US & Europe & Japan \\
\hline $\mathbf{2 0 0 3}$ & $52.0 \%$ & $53.3 \%$ & $68.3 \%$ & $2.7 \%$ & $7.3 \%$ & $0.3 \%$ & $25.0 \%$ & $26.3 \%$ & $18.5 \%$ & $5.4 \%$ & $3.6 \%$ & $1.2 \%$ \\
$\mathbf{2 0 0 4}$ & $52.7 \%$ & $50.5 \%$ & $69.3 \%$ & $2.5 \%$ & $6.1 \%$ & $0.4 \%$ & $25.0 \%$ & $26.3 \%$ & $21.9 \%$ & $5.2 \%$ & $3.2 \%$ & $1.1 \%$ \\
$\mathbf{2 0 0 5}$ & $51.9 \%$ & $46.0 \%$ & $68.1 \%$ & $4.3 \%$ & $6.6 \%$ & $0.6 \%$ & $25.1 \%$ & $25.2 \%$ & $26.0 \%$ & $5.7 \%$ & $3.2 \%$ & $1.4 \%$ \\
$\mathbf{2 0 0 6}$ & $51.0 \%$ & $44.3 \%$ & $69.7 \%$ & $6.2 \%$ & $8.0 \%$ & $1.0 \%$ & $25.4 \%$ & $26.0 \%$ & $25.9 \%$ & $6.5 \%$ & $2.9 \%$ & $1.7 \%$ \\
$\mathbf{2 0 0 7}$ & $50.7 \%$ & $43.3 \%$ & $68.8 \%$ & $6.6 \%$ & $12.3 \%$ & $0.9 \%$ & $24.8 \%$ & $26.5 \%$ & $23.8 \%$ & $6.7 \%$ & $3.2 \%$ & $1.7 \%$ \\
$\mathbf{2 0 0 8}$ & $53.8 \%$ & $42.9 \%$ & $71.4 \%$ & $3.5 \%$ & $9.9 \%$ & $0.7 \%$ & $24.9 \%$ & $27.4 \%$ & $29.8 \%$ & $5.9 \%$ & $3.0 \%$ & $1.4 \%$ \\
$\mathbf{2 0 0 9}$ & $54.2 \%$ & $44.9 \%$ & $71.1 \%$ & $1.8 \%$ & $7.9 \%$ & $0.4 \%$ & $24.8 \%$ & $23.7 \%$ & $23.6 \%$ & $4.6 \%$ & $2.0 \%$ & $1.1 \%$ \\
$\mathbf{2 0 1 0}$ & $54.5 \%$ & $42.3 \%$ & $69.0 \%$ & $1.5 \%$ & $4.2 \%$ & $0.3 \%$ & $24.8 \%$ & $23.5 \%$ & $25.6 \%$ & $4.5 \%$ & $1.9 \%$ & $1.4 \%$ \\
$\mathbf{2 0 1 1}$ & $60.0 \%$ & $42.6 \%$ & $68.4 \%$ & $1.3 \%$ & $4.8 \%$ & $0.2 \%$ & $24.6 \%$ & $23.1 \%$ & $25.9 \%$ & $4.2 \%$ & $2.2 \%$ & $1.4 \%$ \\
$\mathbf{2 0 1 2}$ & $60.4 \%$ & $44.7 \%$ & $68.4 \%$ & $1.0 \%$ & $3.8 \%$ & $0.2 \%$ & $23.2 \%$ & $23.7 \%$ & $25.6 \%$ & $3.8 \%$ & $2.1 \%$ & $1.3 \%$ \\
$\mathbf{2 0 1 3}$ & $61.7 \%$ & $46.5 \%$ & $68.1 \%$ & $0.7 \%$ & $3.5 \%$ & $0.2 \%$ & $22.8 \%$ & $23.8 \%$ & $27.6 \%$ & $3.5 \%$ & $1.9 \%$ & $1.2 \%$ \\
$\mathbf{2 0 1 4}$ & $61.2 \%$ & $45.7 \%$ & $66.7 \%$ & $0.6 \%$ & $3.1 \%$ & $0.2 \%$ & $21.2 \%$ & $24.0 \%$ & $25.7 \%$ & $3.2 \%$ & $2.3 \%$ & $1.0 \%$ \\
$\mathbf{2 0 1 5}$ & $62.7 \%$ & $46.9 \%$ & $67.0 \%$ & $0.6 \%$ & $2.8 \%$ & $0.2 \%$ & $22.4 \%$ & $23.5 \%$ & $27.3 \%$ & $3.1 \%$ & $2.0 \%$ & $0.9 \%$ \\
\hline
\end{tabular}

Table 5 also shows the mean ratio of total interest paid on deposits relative to all interest-bearing deposits. This ratio peaked for all banks in 2006-
2007, reaching a high of $6.6 \%$ for U.S. banks vs. $12.3 \%$ for European banks. Japanese banks' interest on deposits never rises above $1 \%$ for the past 12 
years. Starting in 2008 and continuing through 2015, the ratio of interest on deposits to total deposits trends lower for all banks, but Japanese and U.S. banks enjoy a distinct advantage in this area compared with their European counterparts. Postcrisis, Japanese and U.S. banks have paid rates on deposits that average $5.7 \%$ and $3.6 \%$ less than banks in Europe, respectively. These results help explain why Japanese and U.S banks prefer deposits to other funding sources. The BOJ and U.S. Federal Reserve (FED) have provided support for banks in Japan and the U.S. by maintaining their zero interest rate policies (ZIRP), which has encouraged these banks to increase their use of deposit-based funding while simultaneously lowering their overall cost of capital. The lower interest rates on deposits paid by U.S. banks has undoubtedly helped them achieve the consistently higher net interest margin reported in Table 4. It is difficult to reconcile this finding with the data reported in Figure 3, however, which shows that market interest rates in Europe are substantially lower than similar rates in the U.S. Lower interest rates on European bonds would be expected to correspond to lower, rather than higher, deposit rates. Another puzzle is why Japanese savers are willing to hold deposits at such low yields.

Table 5 also reports the mean earning asset yield for the banks, calculated as interest income relative to total interest earning assets. Once again, U.S. banks enjoy a distinct advantage. Over the entire period 2003-2015, U.S. banks' earning asset yield has averaged $2.2 \%$ higher than European banks and $3.5 \%$ higher than Japanese banks. The combination of a higher net interest margin and earning asset yield and lower average rates paid on deposits contribute to U.S. banks' superior stock price performance and long-term revenue growth.

Table 6.Composition of Bank Assets and Expected Default Frequency

\begin{tabular}{lcccccccccccc} 
& \multicolumn{3}{c}{$\begin{array}{c}\text { Net Loans } \\
\text { to Total Assets }\end{array}$} & \multicolumn{3}{c}{$\begin{array}{c}\text { Investment and Trading } \\
\text { Assets to Total Assets }\end{array}$} & \multicolumn{2}{c}{$\begin{array}{c}\text { Derivative Trading } \\
\text { Assets to Total Assets }\end{array}$} & \multicolumn{3}{c}{$\begin{array}{c}\text { Market Capitalization/ } \\
\text { Total Debt + Capital Leases }\end{array}$} \\
\hline Year & US & Europe & Japan & US & Europe & Japan & US & Europe & Japan & US & Europe & Japan \\
\hline $\mathbf{2 0 0 3}$ & $48.4 \%$ & $56.0 \%$ & $52.0 \%$ & $25.4 \%$ & $26.9 \%$ & $33.5 \%$ & $0.7 \%$ & $1.7 \%$ & $0.0 \%$ & $80.8 \%$ & $57.8 \%$ & $92.6 \%$ \\
$\mathbf{2 0 0 4}$ & $48.6 \%$ & $51.0 \%$ & $51.9 \%$ & $24.4 \%$ & $35.7 \%$ & $33.8 \%$ & $0.6 \%$ & $3.7 \%$ & $1.0 \%$ & $74.8 \%$ & $43.6 \%$ & $102.3 \%$ \\
$\mathbf{2 0 0 5}$ & $47.9 \%$ & $49.2 \%$ & $52.7 \%$ & $25.1 \%$ & $39.4 \%$ & $33.6 \%$ & $0.4 \%$ & $6.9 \%$ & $1.3 \%$ & $64.5 \%$ & $35.1 \%$ & $122.5 \%$ \\
$\mathbf{2 0 0 6}$ & $48.1 \%$ & $48.5 \%$ & $54.4 \%$ & $25.0 \%$ & $40.6 \%$ & $34.4 \%$ & $0.4 \%$ & $6.2 \%$ & $1.3 \%$ & $66.5 \%$ & $39.8 \%$ & $127.7 \%$ \\
$\mathbf{2 0 0 7}$ & $49.3 \%$ & $47.3 \%$ & $54.2 \%$ & $24.1 \%$ & $39.8 \%$ & $35.0 \%$ & $0.5 \%$ & $9.7 \%$ & $2.7 \%$ & $41.7 \%$ & $37.5 \%$ & $144.5 \%$ \\
$\mathbf{2 0 0 8}$ & $52.0 \%$ & $46.1 \%$ & $56.6 \%$ & $21.9 \%$ & $41.4 \%$ & $34.3 \%$ & $2.2 \%$ & $23.0 \%$ & $3.1 \%$ & $24.6 \%$ & $12.6 \%$ & $115.0 \%$ \\
$\mathbf{2 0 0 9}$ & $46.0 \%$ & $47.4 \%$ & $52.2 \%$ & $24.3 \%$ & $40.3 \%$ & $39.3 \%$ & $2.7 \%$ & $15.2 \%$ & $2.6 \%$ & $33.3 \%$ & $24.9 \%$ & $500.7 \%$ \\
$\mathbf{2 0 1 0}$ & $45.6 \%$ & $46.7 \%$ & $48.2 \%$ & $25.7 \%$ & $40.7 \%$ & $39.7 \%$ & $2.5 \%$ & $15.2 \%$ & $2.2 \%$ & $47.6 \%$ & $20.7 \%$ & $100.3 \%$ \\
$\mathbf{2 0 1 1}$ & $47.6 \%$ & $47.3 \%$ & $48.4 \%$ & $23.3 \%$ & $39.9 \%$ & $40.0 \%$ & $2.9 \%$ & $19.5 \%$ & $2.0 \%$ & $52.6 \%$ & $15.1 \%$ & $101.5 \%$ \\
$\mathbf{2 0 1 2}$ & $46.3 \%$ & $45.7 \%$ & $48.2 \%$ & $26.4 \%$ & $40.6 \%$ & $39.2 \%$ & $2.2 \%$ & $16.7 \%$ & $2.1 \%$ & $61.3 \%$ & $21.6 \%$ & $185.0 \%$ \\
$\mathbf{2 0 1 3}$ & $46.4 \%$ & $47.6 \%$ & $47.5 \%$ & $27.3 \%$ & $38.1 \%$ & $34.6 \%$ & $1.8 \%$ & $12.9 \%$ & $1.5 \%$ & $84.9 \%$ & $35.0 \%$ & $274.0 \%$ \\
$\mathbf{2 0 1 4}$ & $45.4 \%$ & $45.9 \%$ & $46.5 \%$ & $29.9 \%$ & $40.5 \%$ & $32.9 \%$ & $2.3 \%$ & $16.0 \%$ & $1.1 \%$ & $82.3 \%$ & $30.6 \%$ & $470.4 \%$ \\
$\mathbf{2 0 1 5}$ & $47.0 \%$ & $47.2 \%$ & $45.7 \%$ & $28.4 \%$ & $39.5 \%$ & $31.5 \%$ & $1.9 \%$ & $13.8 \%$ & $0.0 \%$ & $80.4 \%$ & $25.2 \%$ & $486.5 \%$ \\
\hline
\end{tabular}

I, next, examine the major asset categories for the three sets of banks. Table 6 shows banks' mean ratio of net loans/total assets from 2003-2015. U.S. banks' have held a consistent percentage of total assets in the form of loans following the financial crisis, between 46\%-47\% since 2009. European banks' loan to assets ratio has remained in a similar range as well. The loan/assets ratio for Japanese banks has declined steadily over the same period, from $54 \%$ to under $46 \%$.

Table 6 also shows the annual mean ratio of investment and trading assets to total assets for the three sets of banks. The last year in which U.S. and European banks' levels of investment and trading assets was similar was 2003, with values of $25 \%$ and $27 \%$, respectively. U.S. and Japanese banks' investments in securities and trading assets trended lower leading into the financial crisis years, a period during which European banks were increasing their levels of these assets. European banks' ratio of investment and trading assets to total assets has risen above $40 \%$ in several years, both pre- and postcrisis, while U.S. banks have never held more than $30 \%$ of their total assets in the form of investment securities or trading assets. As banks in Europe have found it difficult to grow their loan portfolios and earn sufficiently large NIMs on lending activity (Figure 2 and Table 3), they have substituted a greater percentage of investment securities and trading assets as a source of revenue. These findings are consistent with the predictions of researchers such as Van Hoose $(2006,2007)$ and Keen (2009) regarding banks holding more alternative assets and fewer loans. Despite earning the lowest NIMs and EAYs, Japanese banks have continued reducing their relative levels of securities and trading assets.

Table 6 also shows the mean ratio of derivative trading assets to total assets. From 2003-2007, U.S. 
banks averaged $0.5 \%$ in this category, Japanese banks averaged $1.3 \%$, and European banks averaged $5.6 \%$. European banks' use of derivatives climbed steadily from $1.7 \%$ to $9.7 \%$ by 2007 . Post-financial crisis, the difference among banks' exposure to derivatives has increased substantially. European banks have held an average of $15.7 \%$ of their assets in the form of derivative securities from 2010-2015, while U.S. banks' use of derivatives has averaged only $2.3 \%$ of total assets, and Japan's only $1.5 \%$. In the case of Europe, these findings are consistent with predictions that revenue-constrained banks will move away from traditional assets such as loans and pursue higher-risk, higher-expected return investments such as trading securities and derivatives. Why Japanese banks are not pursuing similar strategies remains a puzzle.

The final metric shown in Table 6 is the ratio of a bank's market capitalization to total debt plus capital leases. This ratio is the most heavilyweighted component of Moody's (2011) Expected Default Frequency $\left(\mathrm{EDF}^{\mathrm{TM}}\right)$ calculation. In general, the higher the ratio of value to debt, the lower the probability of default. The deteriorating financial position of European vs. U.S. banks in the precrisis period is evident. European banks' value/debt ratio displays a long-term decline to $12.8 \%$ in 2008, and rises moderately back to $35 \%$ by 2013 . The ratio has trended lower in the following 2 years, all the way back down to $25 \%$ by 2015 . As much as any other metric, the mean value/debt ratio depicts European banks' precarious slide closer to insolvency, as these banks owe almost 4 times more to creditors than the market value of their stock. U.S. banks have maintained a far higher value of this ratio, between $80 \%-85 \%$ from 2013-2015, indicating a much lower probability of default. The ratio suggests a complete return to financial health for U.S. banks, and offers little reason for continued coddling by the banker-centric U.S. Federal Reserve. Japanese banks look surprisingly strong based on this metric, with market capitalizations almost five times greater than the book value of their debt and capital leases.

Table 7.Allowances and Provisions for Loan Losses and Tier 1 Capital Ratios

\begin{tabular}{|c|c|c|c|c|c|c|c|c|c|c|c|c|}
\hline \multirow[b]{2}{*}{ Year } & \multicolumn{3}{|c|}{$\begin{array}{l}\text { Impaired, Restructured } \\
\text { or Nonperforming Loans }\end{array}$} & \multicolumn{3}{|c|}{$\begin{array}{l}\text { Allowance for Loan } \\
\text { Losses/Impaired Loans }\end{array}$} & \multicolumn{3}{|c|}{$\begin{array}{l}\text { Provisions for Loan } \\
\text { Losses/Impaired Loans }\end{array}$} & \multicolumn{3}{|c|}{$\begin{array}{c}\text { Tier } 1 \\
\text { Capital Ratio } \\
\end{array}$} \\
\hline & US & Europe & Japan & US & Europe & Japan & US & Europe & Japan & US & Europe & Japan \\
\hline 2003 & $2.0 \%$ & $4.4 \%$ & $7.6 \%$ & $198.2 \%$ & $70.8 \%$ & $35.5 \%$ & $58.5 \%$ & $21.0 \%$ & $0.2 \%$ & $12.3 \%$ & $11.5 \%$ & $6.0 \%$ \\
\hline 2004 & $1.1 \%$ & $3.4 \%$ & $5.3 \%$ & $282.4 \%$ & $105.9 \%$ & $41.7 \%$ & $64.3 \%$ & $19,4 \%$ & $2.9 \%$ & $12.1 \%$ & $9.7 \%$ & $6.5 \%$ \\
\hline 2005 & $0.8 \%$ & $2.8 \%$ & $3,4 \%$ & $326.1 \%$ & $126.5 \%$ & $38.4 \%$ & $116.2 \%$ & $12.7 \%$ & $1.7 \%$ & $11.8 \%$ & $10.5 \%$ & $6.1 \%$ \\
\hline 2006 & $0.7 \%$ & $3.1 \%$ & $2.8 \%$ & $312.8 \%$ & $53.8 \%$ & $39.9 \%$ & $102.1 \%$ & $34.4 \%$ & $5.6 \%$ & $12.1 \%$ & $9.0 \%$ & $6.2 \%$ \\
\hline 2007 & $1.3 \%$ & $3.7 \%$ & $2.6 \%$ & $191.9 \%$ & $71.0 \%$ & $35.3 \%$ & $89.6 \%$ & $20.6 \%$ & $5.1 \%$ & $11.4 \%$ & $8.8 \%$ & $6.7 \%$ \\
\hline 2008 & $2.9 \%$ & $4.4 \%$ & $2.4 \%$ & $165.3 \%$ & $37.5 \%$ & $33.6 \%$ & $73.3 \%$ & $26.3 \%$ & $10.2 \%$ & $13.8 \%$ & $9.1 \%$ & $5.9 \%$ \\
\hline 2009 & $7.4 \%$ & $8.0 \%$ & $3.0 \%$ & $63.2 \%$ & $24.9 \%$ & $36.0 \%$ & $46.4 \%$ & $22.7 \%$ & $7.7 \%$ & $14.4 \%$ & $11.2 \%$ & $8.2 \%$ \\
\hline 2010 & $9.1 \%$ & $11.4 \%$ & $4.2 \%$ & $59.3 \%$ & $24.0 \%$ & $40.9 \%$ & $30.7 \%$ & $9.2 \%$ & $4.5 \%$ & $15.6 \%$ & $10.6 \%$ & $11.7 \%$ \\
\hline 2011 & $8.4 \%$ & $11.6 \%$ & $4.2 \%$ & $51.3 \%$ & $22.0 \%$ & $36.8 \%$ & $14.0 \%$ & $9.8 \%$ & $2.7 \%$ & $15.4 \%$ & $12.6 \%$ & $12.3 \%$ \\
\hline 2012 & $8.6 \%$ & $13.4 \%$ & $4.0 \%$ & $40.8 \%$ & $25.7 \%$ & $35.4 \%$ & $10.4 \%$ & $9.1 \%$ & $1.4 \%$ & $15.3 \%$ & $12.4 \%$ & $11.7 \%$ \\
\hline 2013 & $5.4 \%$ & $17.6 \%$ & $3.1 \%$ & $32.7 \%$ & $21.0 \%$ & $37.7 \%$ & $5.3 \%$ & $5.5 \%$ & $0.3 \%$ & $11.3 \%$ & $10.9 \%$ & $11.4 \%$ \\
\hline 2014 & $6.0 \%$ & $15.3 \%$ & $2.7 \%$ & $43.2 \%$ & $24.9 \%$ & $39.2 \%$ & $7.6 \%$ & $5.0 \%$ & $0.5 \%$ & $12.3 \%$ & $15.8 \%$ & $11.8 \%$ \\
\hline 2015 & $4.9 \%$ & $12.3 \%$ & $2.3 \%$ & $40.5 \%$ & $24.3 \%$ & $46.7 \%$ & $10.5 \%$ & $4.4 \%$ & $4.9 \%$ & $15.0 \%$ & $17.8 \%$ & $11.5 \%$ \\
\hline
\end{tabular}

Table 7 shows the average percentage of banks' loans that are classified as impaired, restructured or nonperforming relative to total net loans. Considered together with the results presented in Table 6, the findings that follow continue to cast doubt on European banks' ability to fully recover from the financial crisis. Pre-financial crisis, U.S. banks' impaired, restructured or nonperforming loans averaged between $0.7 \%-2.0 \%$ of all loans. European banks ran consistently higher levels, ranging from $2.8 \%-4.4 \%$. U.S. banks saw a significant increase in their impaired loans following the financial crisis, which have consistently averaged approximately $7 \%$ of U.S. banks' total loans since 2010 (more than 3 times their pre-crisis levels). European banks show an even more dramatic increase in impaired loans, jumping to $8 \%$ of all loans in 2009 and rising to a high of $18 \%$ by 2013. Since 2010, European banks' ratio of impaired loans has averaged $13.6 \%$, almost twice as large as the average for U.S. banks. While the quality of U.S. banks' loan portfolios remains compromised post-crisis, Europe's loan portfolio quality has failed to show any sign of meaningful recovery. As of year-end 2015, U.S. banks have managed to reduce the percentage of impaired loans in their portfolios to $4.9 \%$, while European banks are averaging $12.3 \%$ in this category. While Japanese banks look surprisingly healthy based on this metric as well, this is actually an artifact of the unusually low interest rates prevailing in Japan, which allow for impaired loans to be refinanced at 
near-zero interest rates, which keeps them from falling into the nonperforming category.

Table 7 also shows banks' mean ratios of both allowances and provisions for loan losses relative to total loans from 2003-2015. Loan loss provisions are transferred out of the allowance for loan losses account on the balance sheet and expensed against bank profits at the discretion of the financial manager, usually in anticipation of loan defaults. Pre-financial crisis, U.S. banks maintained allowances for loan losses that were 2-3 times larger than the impaired loans on their balance sheets. Post-crisis, U.S. banks allowances for loan losses have averaged only $45 \%$ of their impaired loans. These values are not consistent with banks being fully prepared to account for future loan nonperformance, and do not constitute a firm foundation on which their loan portfolios can be expanded in the future.

The trend in the allowances for loan losses ratio for European banks is even more disturbing. The allowance account represents the "rainy day" fund banks establish on the balance sheet in case these funds must be transferred to the income statement in the event of loan defaults. Pre-crisis, European banks set aside between $71 \%-127 \%$ of their impaired loans for possible future write-downs. Post-crisis, European banks are recognizing an average of $24 \%$ of their troubled loans on their balance sheets. The refusal to effectively address these problems, on the parts of both the banks and their regulatory bodies, could hardly be clearer. Japan's allowances of $46.7 \%$ might appear admirable, but in light of their unusually low levels of impaired or nonperforming loans, this ratio is not reassuring.

Table 7 also shows the ratio of loan loss provisions to impaired loans from 2003-2015. The table shows that Japanese, European and U.S. banks continue to write down lower percentages of impaired loans post-crisis, despite a higher level of impaired loans on their balance sheets since 2008. From 2003-2007, U.S. banks took losses of $86 \%$ of their impaired loans on average each year, while European banks expensed an average of $22 \%$ over the same period. From 2010-2015, U.S. banks have written down only $13 \%$ of their impaired loans per year on average, and European banks have written down an average of only 7\% per year. In 2013 and 2014, Japanese banks wrote down less than $1 \%$ of their impaired loans. Based on these ratios, none of these banking systems is demonstrating meaningful recovery during the post-crisis period. The most striking result from Table 7 is that since 2010 banks' allowance accounts relative to impaired loans have been maintained at significantly lower levels than they were pre-crisis. Even though their balance sheets remain ridden with impaired loans, they are setting aside fewer resources to deal with potential loan losses, and expensing a lower percentage of impaired loans each year, which allows them to report substantially higher profits. These practices have undoubtedly arisen to mask the deteriorating revenue growth reported above.

Table 7 also shows the ratio of Tier 1 capital to total assets for the three sets of banks. The Collins Amendment to the Dodd-Frank act requires U.S. banks to significantly increase balance sheet capital, particularly Tier 1 capital holdings, and Basel III has similar provisions. Holding more capital contributes to two opposing effects, however, thus the overall effect of a higher capital ratio is ambiguous (Keeley, 1990, Demsetz et al., 1996; and Hellman et al., 2000). Higher capital ratios discipline banks' risk-taking, as using more of their own capital exposes banks to greater risk. Holding more capital may also decrease stability, however, because it is costly to banks. Future profits may, therefore, be lower, resulting in banks being forced to increase their risk exposure to grow profits. Recent bank crises have increased regulator and shareholder awareness of the importance of adequate capital buffers, with many banks maintaining levels of capital greater than the regulatory minimum as a cushion against the adverse financial consequences of unexpected changes in asset prices. Banks therefore have an incentive to hold excess capital to avoid the costs associated with supervisory action if they approach or fall below the regulatory minimum capital ratio (Marcus, 1984 and Furfine, 2001). Banks may also maintain excess capital as a signal of stability to the market and to satisfy regulators and rating agencies (Jackson et al., 1999 and Shim, 2013). Unfortunately, the numerous Eurozone "stress tests" of banks' capital adequacy employ constantly-shifting capital targets to make stress test results appear better than they otherwise would (Riecher and Black, 2014).

The results reported in Table 7 shows that banks' mean Tier 1 ratios have risen steadily following the financial crisis, with European banks finally exceeding the percentage of Tier 1 capital held by U.S. banks in 2013. With ratios of $15 \%$ and $18 \%$, respectively, both sets of banks appear to be well above the Basel III regulatory minimum of $4 \%$. Japanese banks have also consistently held Tier 1 capital greater than $10 \%$ of total assets post-financial crisis.

\section{Summarizing the results of this section, I find that:}

- Japanese banks consistently run the highest levels of deposits to assets, occasionally exceeding $70 \%$. Japanese and U.S. banks prefer deposits as a source of funding compared with European banks. U.S. banks' deposits/assets ratio reached a post- 
crisis high of $63 \%$ in 2015, while European banks funded less than $47 \%$ of their assets via deposits in 2015.

- Japanese banks pay far lower rates on deposits vs. U.S. and European banks, although European banks' deposit rates are unnaturally high compared with regional interest rates. Postcrisis, U.S. banks have paid an average rate on deposits that is $3.2 \%$ lower than European banks, which helps explain their preference for deposits as a source of funding.

- U.S. banks' earning asset yield (EAY) is significantly higher than their Japanese and European counterparts. Over the entire 20032015 period, U.S. banks EAY averaged 2.2\% higher than European banks and 3.5\% higher than Japanese banks, but has fallen to an average of only $1.5 \%$ and $2.4 \%$ higher, respectively, since 2011.

- Japanese, U.S. and European banks hold similar percentages of loans on their balance sheets, with loans/assets ratios averaging between 46\%-48\% since 2009.

- European banks hold a significantly higher percentage of investment and trading assets compared to Japanese and U.S. banks, averaging over $40 \%$ of total assets, both pre- and post-crisis. Since 2003, U.S. banks have never held more than $30 \%$ of their assets in the form of investment and trading securities. European banks also hold substantially higher levels of derivative securities on their balance sheets.

- The mean percentage of impaired, restructured or nonperforming loans soared for U.S. and European banks post-crisis, but barely rose in Japan. The ratio gradually declined to $4.9 \%$ for U.S. banks by 2015, which is still more than twice their pre-crisis levels. This ratio remains significantly higher for European banks, which continue to carry an average of $12.3 \%$ of impaired loans in their portfolios. This is approximately 3 times their precrisis average. Japanese banks' impaired loan ratio has returned to its pre-crisis level.
- Despite elevated levels of impaired loans postcrisis, U.S. and European banks set aside a smaller percentage of assets on their balance sheets to cover likely loan losses, and expense a smaller percentage of impaired loans on their income statements compared to pre-crisis practices. Japanese banks' allowances and provisions for loan losses show no reaction to the financial crisis, which is not a sign of financial health, but rather the ability to roll over nonperforming loans at near-zero interest rates.

- All sets of banks hold more Tier 1 capital than required by the Basel III accord, although moving risky derivative positions back onto bank balance sheets in the U.S. would change these results significantly, and leave U.S. banks undercapitalized.

\section{Profibility, operational efficiency, tax rates and paouts to investors}

In this section, I examine the profitability, operational efficiency, effective tax rates and payouts to investors from 2003-2015. Table 8 shows the mean annual net profit margin for the three sets of banks. In the pre-crisis period European banks' profit margin rose steadily until peaking at $31.2 \%$ in 2007 , while U.S. banks' net margin peaked in 2006 at 28\%. Net margin for both sets of banks plummeted during the financial crisis and took years to recover. U.S. banks' profit margin has trended steadily higher since 2008, rebounding from a low of $-2.1 \%$ all the way to $25.8 \%$ in 2015. European banks' mean profit margin initially rebounded, then trended back down to a post-crisis low of $9.3 \%$ in 2013, but has gained ground in the past 2 years and achieved a post-crisis high of $18.8 \%$ in 2015 . The difference between U.S. and European banks' ability to generate profits helps to explain U.S. banks' superior stock returns since 2011. Japanese banks' post-crisis net margin has averaged $20.6 \%$ despite being mired in a slow-growth, low-interest rate environment.

Table 8.

\begin{tabular}{|c|c|c|c|c|c|c|c|c|c|c|c|c|}
\hline \multirow[b]{2}{*}{ Year } & \multicolumn{3}{|c|}{ Net Profit Margin } & \multicolumn{3}{|c|}{ Return on Equity } & \multicolumn{3}{|c|}{ Efficiency Ratio } & \multicolumn{3}{|c|}{ Effective Tax Rate } \\
\hline & US & Europe & Japan & us & Europe & Japan & Us & Europe & Japan & us & Europe & Japan \\
\hline 2003 & $27.0 \%$ & $23.6 \%$ & $8.1 \%$ & $18.0 \%$ & $13.8 \%$ & 0.196 & $34.5 \%$ & 45.396 & $12.1 \%$ & $32.1 \%$ & $26.6 \%$ & $28.7 \%$ \\
\hline 2004 & $24.5 \%$ & $26.2 \%$ & $17.8 \%$ & $15.3 \%$ & $15.8 \%$ & $9.7 \%$ & $39.7 \%$ & $53.8 \%$ & $16.8 \%$ & $30.5 \%$ & $25.9 \%$ & $26.1 \%$ \\
\hline 2005 & $28.0 \%$ & 27.896 & $22.3 \%$ & $15,6 \%$ & $17.2 \%$ & $11,7 \%$ & $37.7 \%$ & $45.8 \%$ & 14.796 & $30.4 \%$ & 26.196 & $27.3 \%$ \\
\hline 2006 & $28.0 \%$ & $30.0 \%$ & $22.6 \%$ & $16.6 \%$ & $17.4 \%$ & $9.9 \%$ & $36.4 \%$ & $40.9 \%$ & $15.1 \%$ & $30.6 \%$ & $26.2 \%$ & $36.3 \%$ \\
\hline 2007 & $20.4 \%$ & $31.2 \%$ & 5.99 & $10.9 \%$ & $15.9 \%$ & $3.2 \%$ & $42.5 \%$ & $39.0 \%$ & $12.8 \%$ & $24.4 \%$ & $20.0 \%$ & $22.7 \%$ \\
\hline 2008 & $-2.1 \%$ & $11.6 \%$ & $-33.9 \%$ & $1.1 \%$ & $8.0 \%$ & $-8.9 \%$ & $48.8 \%$ & $45.9 \%$ & $17.3 \%$ & $11.1 \%$ & $20.4 \%$ & $11.8 \%$ \\
\hline 2009 & $9.6 \%$ & $16.7 \%$ & $14.9 \%$ & 5.996 & $7.7 \%$ & 7.296 & $46.3 \%$ & $46.5 \%$ & $19.5 \%$ & $17,4 \%$ & 15.996 & $31.5 \%$ \\
\hline 2010 & $14.8 \%$ & $18.2 \%$ & $15.3 \%$ & $7.0 \%$ & $7.8 \%$ & $5.9 \%$ & $56.3 \%$ & $49.5 \%$ & $24.2 \%$ & $21.1 \%$ & $23.6 \%$ & $37.8 \%$ \\
\hline 2011 & $19.2 \%$ & 14.996 & $17.1 \%$ & $9.0 \%$ & $5.4 \%$ & $7.0 \% 6$ & $60.7 \%$ & $53.1 \%$ & $25.1 \%$ & $26.0 \%$ & $20.5 \%$ & $38.9 \%$ \\
\hline 2012 & $19.0 \%$ & $11.1 \%$ & $23.7 \%$ & $8.7 \%$ & $4.2 \%$ & $9.4 \%$ & $64.0 \%$ & $60.7 \%$ & $16.9 \%$ & $20.1 \%$ & $18.7 \%$ & 20.096 \\
\hline 2013 & $21.8 \%$ & 9.396 & $23.4 \%$ & $9.1 \%$ & $3.6 \%$ & $8,8 \%$ & 62.896 & $57.4 \%$ & $32.2 \%$ & $31.0 \%$ & 21.296 & $29.8 \%$ \\
\hline 2014 & $20.9 \%$ & $16.7 \%$ & $24.0 \%$ & $8.4 \%$ & $6.3 \%$ & $8.7 \%$ & $64.6 \%$ & $54.8 \%$ & $14.6 \%$ & 32.09 & $34.5 \%$ & $32.6 \%$ \\
\hline 2015 & 25.89 & $18.8 \%$ & 20.196 & $9.4 \%$ & 6.698 & 6.496 & $58.9 \%$ & $57.4 \%$ & 4.19 & $27.3 \%$ & $23.5 \%$ & $29.9 \%$ \\
\hline
\end{tabular}


Table 8 also shows the mean return on equity (ROE). European banks' ROE was consistently higher than that of U.S. and Japanese banks precrisis, ranging between $13.8 \%-17.4 \%$ from 20042007. U.S. banks' ROE fell more sharply in 2009, down to $1.1 \%$, but has rebounded more strongly than European banks' ROE since 2010. Japanese banks' ROE plunged all the way to $-8.9 \%$ in 2009 , but quickly rebounded. As of 2015, ROE for all three sets of banks remains far lower than their pre-crisis levels, averaging only $9.4 \%$ for U.S. banks, $7.7 \%$ for Japanese banks, and 6.6\% for European banks in 2015.

Banks' mean efficiency ratio, calculated as total noninterest expense divided by total revenue, is also shown in Table 8. This ratio is often used as a measure of banks' operational efficiency. Japanese, U.S. and European banks all saw increases in this ratio post- crisis. As of 2015 European and U.S. banks have virtually identical efficiency ratios, with values of 59\% and 57\%, respectively, but Japan has posted inexplicably low efficiency ratios in 2014 and 2015. The increases in operating costs for U.S. and European banks most likely reflect their efforts to adapt to the new regulatory frameworks imposed on them postcrisis.

Table 8 also shows banks' mean effective tax rate from 2003-2015. U.S. and European banks are paying lower average tax rates post-crisis, while Japanese banks are paying higher rates, averaging 31.5\% since 2010. Despite higher revenues and profits, U.S. banks have paid an average post-crisis tax rate of only $26.3 \%$, which represents another perk for their bottom lines, as they have been allowed to book more of their revenue as profit due to lower tax rates.

Table 9. Payout Ratios and Yields Based on Dividends and Dividends Plus Stock Repurchases

\begin{tabular}{|c|c|c|c|c|c|c|c|c|c|c|c|c|}
\hline \multirow[b]{2}{*}{ Year } & \multicolumn{3}{|c|}{$\begin{array}{l}\text { Dividends } \\
\text { to Total Revenue }\end{array}$} & \multicolumn{3}{|c|}{$\begin{array}{c}\text { Dividends + Repurchases } \\
\text { to Total Revenue }\end{array}$} & \multicolumn{3}{|c|}{$\begin{array}{l}\text { Dividend } \\
\text { Yield }\end{array}$} & \multicolumn{3}{|c|}{$\begin{array}{c}\text { Dividends Plus } \\
\text { Repurchases Yield }\end{array}$} \\
\hline & US & Europe & Japan & US & Europe & Japan & US & Europe & Japan & US & Europe & Japan \\
\hline 2003 & $9.4 \%$ & $11.3 \%$ & $1.3 \%$ & $17.2 \%$ & $12.7 \%$ & $0.7 \%$ & $2.8 \%$ & $3.8 \%$ & $0.5 \%$ & $5.1 \%$ & $4.2 \%$ & $0.7 \%$ \\
\hline 2004 & $11.1 \%$ & $11.4 \%$ & $1.4 \%$ & $18.3 \%$ & $15.6 \%$ & $3.8 \%$ & $3.3 \%$ & $3.9 \%$ & $0.6 \%$ & $5.2 \%$ & $5.2 \%$ & $3.8 \%$ \\
\hline 2005 & $11.4 \%$ & $11.8 \%$ & $1.7 \%$ & $22.8 \%$ & $16.0 \%$ & $4.0 \%$ & $3.6 \%$ & $4.2 \%$ & $0.4 \%$ & $7.2 \%$ & $5.3 \%$ & $4.0 \%$ \\
\hline 2006 & $11.6 \%$ & $12.6 \%$ & $2.4 \%$ & $23.0 \%$ & $20.4 \%$ & $8.1 \%$ & $3.4 \%$ & $4.0 \%$ & $0.7 \%$ & $6.8 \%$ & $6.1 \%$ & $8.1 \%$ \\
\hline 2007 & $12.2 \%$ & $15.3 \%$ & $3.3 \%$ & $21.9 \%$ & $28.3 \%$ & $3.1 \%$ & $5.2 \%$ & $5.0 \%$ & $1.6 \%$ & $9.1 \%$ & $9.2 \%$ & $3.0 \%$ \\
\hline 2008 & $11.5 \%$ & $7.6 \%$ & $4.0 \%$ & $12.6 \%$ & $18.4 \%$ & $6.4 \%$ & $8.1 \%$ & $5.2 \%$ & $2.4 \%$ & $8.6 \%$ & $12.5 \%$ & $6.3 \%$ \\
\hline 2009 & $1.5 \%$ & $6.8 \%$ & $3.4 \%$ & $1.6 \%$ & $13.5 \%$ & $4.6 \%$ & $1.0 \%$ & $2.7 \%$ & $2.5 \%$ & $1.1 \%$ & $5.7 \%$ & $4.5 \%$ \\
\hline 2010 & $1.0 \%$ & $7.1 \%$ & $4.3 \%$ & $1.9 \%$ & $12.0 \%$ & $11.8 \%$ & $0.5 \%$ & $3.4 \%$ & $3.2 \%$ & $1.0 \%$ & $6.4 \%$ & $11.8 \%$ \\
\hline 2011 & $2.7 \%$ & $7.1 \%$ & $4.7 \%$ & $5.8 \%$ & $12.1 \%$ & $5.2 \%$ & $1.6 \%$ & $4.1 \%$ & $3.1 \%$ & $3.7 \%$ & $7.6 \%$ & $5.1 \%$ \\
\hline 2012 & $3.5 \%$ & $8.1 \%$ & $4.6 \%$ & $6.1 \%$ & $12.0 \%$ & $3.8 \%$ & $1.7 \%$ & $3.5 \%$ & $2.4 \%$ & $2.8 \%$ & $6.0 \%$ & $3.7 \%$ \\
\hline 2013 & $4.4 \%$ & $8.7 \%$ & $5.1 \%$ & $9.4 \%$ & $12.0 \%$ & $4.6 \%$ & $1.6 \%$ & $3.2 \%$ & $2.6 \%$ & $3.5 \%$ & $4.7 \%$ & $4.5 \%$ \\
\hline 2014 & $5.2 \%$ & $10.2 \%$ & $5.0 \%$ & $11.5 \%$ & $12.4 \%$ & $4.2 \%$ & $1.7 \%$ & $3.7 \%$ & $2.5 \%$ & $3.8 \%$ & $4.8 \%$ & $4.1 \%$ \\
\hline 2015 & $5.8 \%$ & $11.1 \%$ & $5.5 \%$ & $13.2 \%$ & $14.4 \%$ & $6.2 \%$ & $2.0 \%$ & $4.1 \%$ & $3.7 \%$ & $4.7 \%$ & $5.7 \%$ & $6.2 \%$ \\
\hline
\end{tabular}

Table 9 shows bank' payout ratios, which I have calculated in an unorthodox manner due to extremely volatile bank profits around the financial crisis. In the exhibits that follow I express banks' dividends and share repurchase relative to total revenue rather than net income to avoid examining an overly noisy data series. Bank dividends relative to revenues were in a rising trend for all banks precrisis, reaching highs of $12.2 \%$ for U.S. banks and $15.3 \%$ for European banks in 2007, but only $4.0 \%$ for Japanese banks in 2008. Post crisis, U.S. banks have reduced their dividend payout dramatically. As of 2015 U.S. banks' mean dividend/revenue ratio stood at $5.8 \%$, but European banks have largely restored their pre-crisis payouts, paying dividends that average $11.1 \%$ of revenues. Japanese banks are also paying out at record levels, equal to $5.5 \%$ of total revenues in 2015. The reduced payout ratios for U.S. banks post-crisis reflect the need to raise additional capital, with retaining earnings being one of the most direct methods for accomplishing this.
U.S. banks' reluctance to increase dividends to the same extent as Japanese and European banks may be a signal of a lack of confidence over the sustainability of recent increases in profits.

Banks' dividend yield (dividend/price) from 20032015 is also shown in Table 9. U.S. banks' dividend yield averaged $3.7 \%$ pre-crisis, and but has averaged only $1.5 \%$ since 2010 . The large reduction in dividends that begins in 2009 takes the average U.S. yield all the way down to $0.5 \%$ in 2010 , after which it climbs to $2.0 \%$ in 2015, well below its pre-crisis average of $3.7 \%$. European banks' dividend yield shows a similar but less severe pattern, averaging $3.7 \%$ in the post-crisis years, vs. an average of $4.2 \%$ pre-crisis. Japanese banks' higher payout ratios are also reflected in higher dividend yields, which only averaged $0.8 \%$ pre-crisis, but have averaged a respectable $2.9 \%$ 2010-2015.

Summarizing the results of this section, I find that: 
- All banks experienced profound declines in their net profit margins and return on equity during the financial crisis. Although banks' net margins have rebounded post-crisis (between 18.8\%-25.8\%), they remain well below their pre-crisis levels.

- Bank's ROE shows less of a recovery post-crisis, as banks have been required to hold more shareholder equity as part of their efforts to boost Tier 1 capital.

- U.S. and European banks' efficiency ratios (noninterest expense/revenue) have risen substantially post-crisis, most likely as a result of increases in regulatory requirements in the post-crisis period. Higher operating expenses have hampered profit generation for both sets of banks. Japanese banks have achieved remarkable operating efficiency in recent years, which has helped boost their net margins and ROE.

- U.S. banks pay a higher effective tax rate than European banks, although both sets of banks are paying lower rates since 2009. Japanese banks have paid the highest effective tax rates since 2010, averaging $31.5 \%$.

- European banks have higher dividend payout ratios than Japanese and U.S. banks and higher dividend yields, despite their lower profitability.

\section{Analysis of bank stock volatility}

In this section, I analyze the volatility of bank stock returns for Japanese, U.S. and European banks using the generalized autoregressive conditional heteroscedasticity (GARCH) method of Engle (1982) and Bollerslev (1986). The GARCH volatility of both sets of banks, along with Deutsche Bank (which is experiencing a borderline liquidity crisis in October 2016), are modeled using maximum likelihood estimation as shown below:
The first equation represents the mean equation, which regresses a vector of stock returns ( $y$ ) on a constant term $(\alpha)$ and a vector of explanatory variables $(X)$. The error terms from the first equation $(\varepsilon)$ are used to model the conditional volatility of the $y$-variable, expressed as a function of a constant term $(c), a$ lagged mean equation error terms $(\varepsilon)$, and $g$ lagged conditional variance terms $\left(\sigma^{2}\right)$. The best-fitting model is determined by minimizing Akaike's Information Criterion.

The analysis in sections 2-5 above shows that banks in Japan, the U.S. and Europe have not fully recovered from the financial crisis and continue to face numerous challenges, including growing revenues and restoring pre-crisis levels of profitability while managing loan portfolios that remain significantly impaired. The overall profitability and financial stability of U.S. banks is found to be superior to that of Japanese and European banks, however. Estimating the time series volatility of both sets of banks using GARCH methods allows me to test whether the effect of monthly shocks to the mean equation are contained to the particular calendar month, or if these shocks to bank stock returns are instead "spilling over" and affecting bank stock returns and volatility in subsequent months. If the ARCH $(\varepsilon)$ and GARCH $\left(\sigma^{2}\right)$ terms are insignificant in the model, then shocks to the mean equation are fully contained within each calendar month. On the other hand, if the ARCH and/or GARCH terms are significant, then shocks to the time series of bank stock returns are persistent, and volatility from past periods is affecting contemporaneous volatility. The table below presents the results from estimation of Equation (1): $y_{t}=\alpha+\beta X_{t}+\varepsilon_{t}$ $\sigma_{t}^{2}=c+\rho \varepsilon_{t-a}+\phi \sigma_{t-g}^{2}$

Table 10. Conditional Variance of Bank Stock Returns

\begin{tabular}{|l|c|c|c|}
\hline \multicolumn{1}{|c|}{ Variable } & US & Europe & Japan \\
\hline Mean Equation Constant & 0.00970 & -0.00911 & -0.00569 \\
\hline z-statistic & 1.213 & -2.710 & -1.470 \\
\hline Nikkei 225 & & & 0.74292 \\
\hline$z$-statistic & & & 2.406 \\
\hline Variance Equation Constant & 0.00189 & 0.00080 & 0.00015 \\
\hline -statistic & 1.165 & 1.736 & 0.630 \\
\hline Epsilon-1 & 0.27140 & 0.23348 & -0.22399 \\
\hline z-statistic & 1.020 & 2.759 & -1.846 \\
\hline GARCH-1 & 0.09849 & 1.53001 & 1.15135 \\
\hline z-statistic & 0.156 & 24.352 & 7.403 \\
\hline GARCH-2 & & -0.68890 & \\
\hline z-statistic & & -17.721 & \\
\hline R-squared & $0.0 \%$ & $0.0 \%$ & $43.4 \%$ \\
\hline Adjusted R-Squared & $0.0 \%$ & $0.0 \%$ & $42.5 \%$ \\
\hline Akaike Information Criterion & -2.912 & -2.345 & -3.530 \\
\hline Schwarz-Bayes Criterion & -2.780 & -2.180 & -3.366 \\
\hline
\end{tabular}

Notes: Variables significant at the $1 \%$ or $5 \%$ levels are shown in bold. 
Table 10 and Figure 4 present the results of the GARCH estimation. For the returns of both the U.S. and European banks (capitalization-weighted averages of each bank's monthly return), the mean equation consists of a constant only, as each index represents a diversified portfolio, with unsystematic risks pertaining to the banking industry largely diversified away. For Japan's bank stock returns, the mean equation of best fit (that minimizes Akaike's Information Criterion) also includes the returns to the Nikkei 225, so that systematic risk associated with the overall Japanese stock market can be captured by the $\beta$ term.

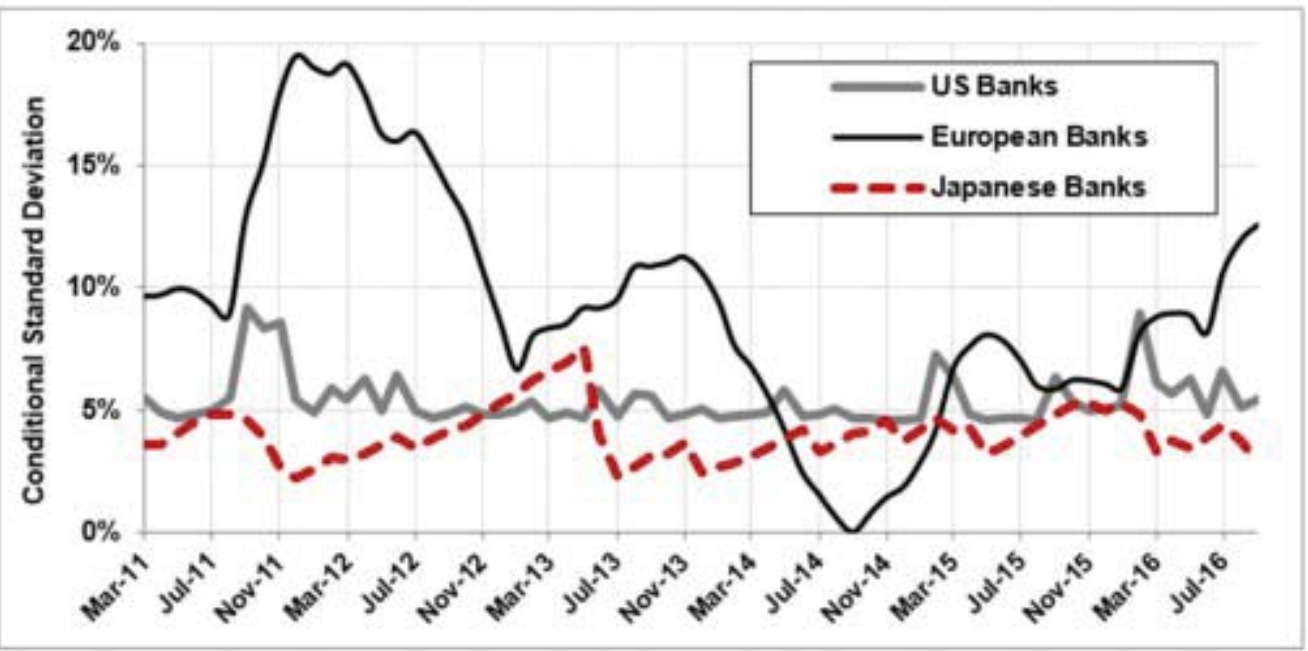

Fig. 4. Conditional Volatility of Monthly Stock Returns for U.S., European and Japan Bank Stocks, March 2011-September 2016

The first column of Table 10 shows that the volatility of U.S. bank stock returns contain no significant ARCH or GARCH terms. This is consistent with the conclusions of the analysis in the previous sections, which determines that U.S. banks have exhibited a more substantial recovery from the financial crisis than European banks. The second column of Table 10 shows that European bank stocks' volatility is best modeled as a function of two lagged conditional variance terms, which is consistent with the idea that European bank stocks are riskier, and that monthly shocks to the time series of European bank stock returns are spilling over and affecting volatility in subsequent months. The third column of Table 10 shows the GARCH model of best fit for Japanese banks' monthly returns. Japanese bank stock returns also contain significant GARCH terms at two lags, which also supports the idea that shocks to their monthly time series of returns are spilling over and affecting volatility in subsequent months. Overall, the GARCH analysis is consistent with the notion that European and Japanese banks continue to experience crisis-level conditions, and that any evidence that these banks have recovered from the financial crisis is fragile at best.

\section{Summary and conclusions.}

In this paper, I compare the financial performance, growth, asset mix, risk, operational efficiency, profitability and capital holdings of the 20 largest commercial banks in Japan, the U.S. and Europe from 2003-2015. I find that the stocks of U.S. commercial banks continued outperforming Japanese and European banks during the 2014-2015 period, but all three sets of banks underperformed their regional stock indexes from 2014-2015. Large banks in Japan, the U.S. and Europe continue to struggle to grow their total revenue post-crisis. Total revenue has declined by a full $20 \%$ for all three sets of banks since 2011. The 20 largest banks in Europe are in a multiyear downward spiral, evidenced by dramatic declines in market capitalization, the book value of loans and total assets, and the level of deposits. Japanese bank performance is stagnant compared to Europe and the U.S. Both Japanese and European banks are particularly challenged by persistently lower net interest margins compared to U.S. banks.

Japanese and U.S. banks prefer deposits as a source of funding compared with European banks, most likely because these banks pay an average rate on deposits that is significantly lower than European banks. U.S. banks' also have an earning asset yield (EAY) that is $1.5 \%$ higher than European banks and 2.4\% higher than Japanese banks since 2011. Japanese, U.S. and European banks' loans/assets ratio has averaged between $46 \%-48 \%$ since 2009 , but European banks hold a significantly higher percentage of investment and trading assets and derivative securities compared with Japanese and U.S. banks.

The mean percentage of impaired, restructured or nonperforming loans soared for U.S. and European banks post-crisis, but barely rose in Japan. While 
this ratio gradually declined to $4.9 \%$ for U.S. banks by 2015, European banks continue to carry an average of $12.3 \%$ of impaired loans in their portfolios, which is approximately 3 times their precrisis average. Despite elevated levels of impaired loans, U.S. and European banks set aside a smaller percentage of assets on their balance sheets to cover likely loan losses, and expense a smaller percentage of impaired loans on their income statements compared to pre-crisis practices. Japanese, U.S. and European banks all hold more Tier 1 capital than required by the Basel III accord, although moving risky derivative positions back onto bank balance sheets in the U.S. would change these results significantly, and most likely leave U.S. banks undercapitalized.

All banks experienced profound declines in their net profit margins and return on equity during the financial crisis. Although all banks' net margins have rebounded post-crisis (between 18.8\%-25.8\%), but remain well below their pre-crisis levels. Banks' ROE shows less of a recovery post-crisis, as banks have been required to hold more shareholder equity to boost Tier 1 capital. U.S. and European banks' efficiency ratios (non-interest expense/revenue) have risen substantially post-crisis, most likely as a result of increases in regulatory requirements, while Japanese banks have achieved remarkable improvements in operating efficiency. Higher operating expenses have hampered profit generation for U.S. and European banks. U.S. banks pay a higher effective tax rate than European banks, although both sets of banks are paying lower rates since 2009. Japanese banks have paid the highest effective tax rates since 2010, averaging 31.5\%. European banks have higher dividend payout ratios than Japanese and U.S. banks and higher dividend yields, despite their lower profitability.

Modeling the conditional volatility of U.S., Japanese and European banks provides evidence consistent with the idea that U.S. banks continue to exhibit a more robust post-crisis recovery, while Japanese and European banks continue to experience crisis-level conditions. Any evidence that Japanese and European banks have recovered from the financial crisis is fragile at best.

\section{References}

1. Acharya, V. V. and Steffen, S. (2014). The 'Greatest' Carry Trade Ever? Understanding Eurozone Bank Risks. Journal of Financial Economics, forthcoming.

2. Ayadi, R., Arbak, E., and W. Pieter de Groen. (2012). Regulation of European Banks and Business Models: Towards a New Paradigm? Center for European Policy Studies, Brussels.

3. Baele, L., Bruyckere, V., De Jonghe, O. and Vander Vennet, R. 2013. Model Uncertainty and Systematic Risk in U.S. Banking. Working paper, January 10, 2013. Available at SSRN: http://ssrn.com/abstract=2216563.

4. Baron, M. and Xong, W. (2014). Credit Expansion and Neglected Crash Risk. Working paper, Princeton University. Available at: http://www.princeton.edu/ mdbaron/CreditExpansion.pdf.

5. Basel Committee on Banking Supervision. (2010). Basel III: A Global Regulatory Framework for More Resilient Banks and Banking Systems.

6. Beccalli, E, Casu, B., and Girardone, C. (2006). Efficiency and Stock Performance in European Banking. Journal of Business Finance and Accounting, 33, pp. 245-262.

7. Black, J., Sirletti S. and Moshinsky, B. ECB Said to Favor Six Percent Capital Requirement in Stress Test. Bloomberg Businessweek (January 14, 2014): http://www.businessweek.com/news/2014-01-15/ecb-said-to-favor6-percent-capital-requirement-in-stress-test-of-banks (accessed July 14, 2014).

8. Bollerslev, (1986). T. Generalized Autoregressive Conditional Heteroskedasticity. Journal of Econometrics, $31 \mathrm{pp}$. 307-327.

9. Buch, C. and Neugebauer, K. (2011). Bank-Specific Shocks and the Real Economy. Journal of Banking and Finance, 35 pp. 2179-2187.

10. Buttiglione, L., Lane, P., Reichlin, L., and Reinhart, V. (2014). Deleveraging? What Deleveraging? Geneva Reports on the World Economy 16, International Center for Monetary and Banking Studies.

11. Catão, L. and G.M. Milesi-Ferretti. (2013). External Liabilities and Crises. IMF Working Paper No. $13 / 113$

12. Coppela, F. (2014). Austria Falls Out with Bavaria over Zombie Banks, Forbes Magazine, Available at: http://www.forbes.com/sites/francescoppola/2014/06/28/austria-and-bavaria-a-tale-of-zombie-banks/

13. Correa, R., Lee, K., Sapriza, H. and Suarez, G. (2014). Sovereign Credit Risk, Banks' Government Support, and Bank Stock Returns Around the World. Journal of Money, Credit and Banking 46 pp. 93-121.

14. Demirguc-Kunt, A., Huizinga, H. (2010). Are Banks Too Big to Fail or Too Big to Save? International Evidence from Equity Prices and CDS Spreads. CEPR Discussion Papers, Center for Economic Policy Research.

15. Demsetz, R.S., Saindenberg, M.R., Strahan, P.E. (1996). Banks with Something to Lose: The Disciplinary Role of Franchise Value. FRBNY Economic Policy Review, 2, pp. 1-14.

16. Engle, R. (1982). Autoregressive Conditional Heteroskedasticity with Estimates of the Variance of United Kingdom Inflation. Econometrica, 61 pp. 987-1007. 
17. Enrich, D., Strasburg, J. and Henning, E. (2014). Deutsche Bank Suffers From a Litany of Reporting Problems, Regulators Said. The Wall Street Journal. Available at: http://online.wsj.com/articles/deutsche-bank-suffers-fromlitany-of-reporting-problems-regulators-said-1406058151.

18. Evans-Pritchard, Ambrose. (2016). Olivier Blanchard Eyes Ugly 'End Game' for Japan on Debt Spiral. The UK Telegraph.

19. Filbeck, G., Preece, D. and Zhao, X. (2011). Top Performing Banks: Size Effect and Economic Cycles. Journal of Investing, 20 pp. 19-32.

20. Filson, D. and S. Olfati. (2014). The Impacts of Gramm-Leach-Bliley Bank Diversification on Value and Risk. Journal of Banking and Finance, 41 209-221.

21. Fisher, Irving. (1933). The debt-deflation theory of great depressions, Econometrica1 337-357.

22. Furfine, C. (2001). Bank Portfolio Allocation: The Impact of Capital Requirements, Regulatory Monitoring and Economic Conditions. Journal of Financial Sesdrvices Research 20 33-56.

23. Gerken, A., Guse, F., Heuser, M., Monguzzi, D., Plantefeve, O. and Poppensieker, T. (2013). Between Deluge and Drought: The Divided Future of European Bank-Funding Markets. McKinsey Working Papers on Risk, No. 41

24. Goss, A. and Roberts, G. (2011). The Impact of Corporate Social Responsibility on the Cost of Bank Loans. Journal of Banking and Finance, 35 pp. 1794-1810.

25. Gourinchas, P.O. and M. Obstfeld. (2013). Stories of the Twentieth Century for the Twenty-First. American Economic Journal: Macroeconomics, 4 pp. 226-65.

26. Hellman, T., Mudock, K., Stiglitz, J.E. Liberalization, (2000), Moral Hazard in Banking and Prudential Regulation: Are Capital Controls Enough? American Economic Review 90, 147-165.

27. Jackson, P., Furfine, C., Groeneveld, H., Hancock, D., Jones, D., Perraudin, W., Radecki, L., and Yoneyama, M. (1999). Capital Requirements and Bank Behavior: The Impact of the Basel Accord. Basel Committee on Banking Supervision, Working Paper No. 1.

28. Kanas, A. (2013). Bank Dividends, Risk and Regulatory Regimes. Journal of Banking and Finance 37, 1-10.

29. Keeley, M.C. (1990), Deposit Insurance, Risk and Market Power in Banking. American Economic Review, 80 pp.1183-1200.

30. Keen, S. (2009). The Global Financial Crisis, Credit Crunches and Deleveraging. Journal of Australian Political Economy 64, 18-32.

31. Kretzschmar, G., McNeil, A., and Kirchner, A. (2010), Integrated Models of Capital Adequacy -Why Banks are Undercapitalized. Journal of Banking and Finance 34, 2838-2850.

32. Marcus, A. (1984). Deregulation and Bank Financial Policy. Journal of Banking and Finance 8, 557-565.

33. Minsky, Hyman. (1977). The Financial Instability Hypothesis: An Interpretation of Keynes and an Alternative to 'Standard' Theory. Nebraska Journal of Economics and Business 16 5-16.

34. Moody's Analytics. EDF Overview (2013). Available at http://www.moodysanalytics.com/ /media/Brochures/Credit-Research-Risk-Measurement/QuantativeInsight/CreditEdge/EDF-Expected-Default-Frequency-Overview.ashx (accessed September 21, 2014).

35. Murphy, M. (2010).The Dodd-Frank Wall Street Reform and Consumer Protection Act: Titles III and VI, Regulation of Depository institutions and Depository Institution Holding Companies. Congressional Research Service Report for Congress.

36. Takita, Yoichi. (2015).Is Quantitative Easing Putting the Bank of Japan's Solvency at Risk? Nikkei Asian Review.

37. Onaran, Y. U.S.( 2013). Banks Bigger Than GDP as Accouting Rift Masks Risks. Bloomberg.com. Available at http://www.bloomberg.com/news/2013-02-20/u-s-banks-bigger-than-gdp-as-accounting-rift-masks-risk.html (accessed September 21, 2014).

38. Oprita, A. (2010). Extra Bank Capital Means Global Recession: Bove. CNBC.com. Available at http://www.cnbc.com/id/43377170 (accessed June 27, 2011).

39. Price, Waterhouse, Coopers. (2010).Impact On Banks, Thrifts, and Their Holding Companies in the A Closer Look at the Dodd-Frank Wall Street Reform and Consumer Protection Act series.

40. Riecher, S. and Black J. (2013). ECB Capital Definition Tougher in Stress Test Than Review. Bloomberg.com Available at: http://www.bloomberg.com/news/2013-10-23/ecb-applies-8-capital-buffer-to-124-banks-in-assettest.html (accessed July 14, 2014).

41. Santos, J. (2001), Bank Capital Regulation in Contemporary Banking Theory: A Review of the Literature. Financial Markets, Institutions, and Instruments, 10. Pp. 41-84.

42. Schildback, J., Wenzel, C. and Speyer, B. Bank Performance in the U.S. and Europe. Deutsche Bank Research (September 26, 2013).

43. Shim, J. (2013). Bank Capital Buffer and Portfolio Risk: The Influence of Business Cycle and Revenue Diversification. Journal of Banking and Finance 37 761-772.

44. Stolz, S. (2002). The Relationship Between Bank Capital, Risk-Taking, and Capital Regulation: A Review of the Literature. Manuscript, Kiel Institute for World Economics.

45. VanHoose, D. ( 2016). Bank Behavior Under Capital Regulation: What Does The Academic Literature Tell Us? Networks Financial Institute Working Paper (2006-WP-04). 
46. VanHoose, (2007). D. Theories of Bank Behavior Under Capital Regulation. Journal of Banking and Finance 31, 3680-3697.

47. Weigand, R. (2013). The Recovery of US Commercial Banking: An Analysis of Revenues, Profits, Dividends, Capital and Value Creation. Banks and Bank Systems 8, No. 3 pp. 76-88.

48. Weigand, R. (2015). ATale of Two Banking Systems: The Performance of U.S. and European Banks in the $21^{\text {st }}$ Century. Investment Management and Financial Innovations 11, No. 1 pp. 8-24.

49. Yang, J. and K. (2012). Tsatsaronis. Bank Stock Returns, Leverage and the Business Cycle. Bank for International Settlements Quarterly Review, pp. 45-59. 